\title{
Metagenomic identification, purification and characterisation of the Bifidobacterium adolescentis BgaC $\beta$-galactosidase
}

\author{
Daniel Mehabie Mulualem ${ }^{1} \cdot$ Christy Agbavwe ${ }^{1} \cdot$ Lesley A. Ogilvie ${ }^{2} \cdot$ Brian V. Jones $^{3} \cdot$ Michelle Kilcoyne $^{1} \cdot$ \\ Conor O'Byrne ${ }^{1} \cdot$ Aoife Boyd ${ }^{1}$ (D)
}

Received: 27 October 2020 / Revised: 19 December 2020 / Accepted: 27 December 2020 / Published online: 11 January 2021

(C) The Author(s) 2021

\begin{abstract}
Members of the human gut microbiota use glycoside hydrolase (GH) enzymes, such as $\beta$-galactosidases, to forage on host mucin glycans and dietary fibres. A human faecal metagenomic fosmid library was constructed and functionally screened to identify novel $\beta$-galactosidases. Out of the 16,000 clones screened, $30 \beta$-galactosidase-positive clones were identified. The $\beta$ galactosidase gene found in the majority of the clones was $B A D \_1582$ from Bifidobacterium adolescentis, subsequently named bgaC. This gene was cloned with a hexahistidine tag, expressed in Escherichia coli and His-tagged-BgaC was purified using $\mathrm{Ni}^{2+}$-NTA affinity chromatography and size filtration. The enzyme had optimal activity at $\mathrm{pH} 7.0$ and $37^{\circ} \mathrm{C}$, with a wide range of $\mathrm{pH}(4-10)$ and temperature $\left(0-40^{\circ} \mathrm{C}\right)$ stability. It required a divalent metal ion co-factor; maximum activity was detected with $\mathrm{Mg}^{2+}$, while $\mathrm{Cu}^{2+}$ and $\mathrm{Mn}^{2+}$ were inhibitory. Kinetic parameters were determined using ortho-nitrophenyl- $\beta$-Dgalactopyranoside (ONPG) and lactose substrates. BgaC had a $V_{\max }$ of $107 \mu \mathrm{mol} / \mathrm{min} / \mathrm{mg}$ and a $K_{m}$ of $2.5 \mathrm{mM}$ for ONPG and a $V_{\max }$ of $22 \mu \mathrm{mol} / \mathrm{min} / \mathrm{mg}$ and a $K_{m}$ of $3.7 \mathrm{mM}$ for lactose. It exhibited low product inhibition by galactose with a $K_{i}$ of $116 \mathrm{mM}$ and high tolerance for glucose (66\% activity retained in presence of $700 \mathrm{mM}$ glucose). In addition, BgaC possessed transglycosylation activity to produce galactooligosaccharides (GOS) from lactose, as determined by TLC and HPLC analysis. The enzymatic characteristics of $B$. adolescentis BgaC make it an ideal candidate for dairy industry applications and prebiotic manufacture.
\end{abstract}

\section{Key points}

- Bifidobacterium adolescentis BgaC $\beta$-galactosidase was selected from human faecal metagenome.

- BgaC possesses sought-after properties for biotechnology, e.g. low product inhibition.

- BgaC has transglycosylation activity producing prebiotic oligosaccharides.

Keywords Enzyme screening $\cdot$ Metagenomic library $\cdot \beta$-Galactosidase $\cdot$ Bifidobacterium $\cdot$ Transglycosylation

\section{Introduction}

$\beta$-Galactosidases (E.C.3.2.1.23) are enzymes that catalyse the hydrolytic cleavage of galactose residues from the non-

Aoife Boyd

aoife.boyd@nuigalway.ie

1 Discipline of Microbiology, School of Natural Sciences, National University of Ireland Galway, Galway, Ireland

2 Max Planck Institute for Molecular Genetics, Berlin, Germany

3 Department of Biology \& Biochemistry, University of Bath, Bath, UK reducing end of $\beta$-galactosides. $\beta$-Galactosidases belong to the six glycoside hydrolase families of GH 1, GH 2, GH 35, GH 42, GH 59, and GH 147 within the Carbohydrate-Active enZymes (CAZy) database (http://www.cazy.org/) (Lombard et al. 2014). In the past decades, there has been a growing interest in identification and characterisation of $\beta$-galactosidases, primarily for application in dairy industries due to their hydrolysis of lactose into glucose and galactose (Adam et al. 2004). Lactose hydrolysis reduces crystallisation problems resulting from the low solubility of lactose and increases the sweetness of dairy products (Gänzle et al. 2008), and the reduced lactose content in whey by-product decreases water pollution (Mawson 1994). Furthermore, the demand for lactose-free dairy products has increased due to the growing 
number of lactose-intolerant people worldwide, reported to be between 2 and $70 \%$ in Europe and the USA and approximately $100 \%$ in Asia (Vandenplas 2015). In addition, some $\beta$ galactosidases can carry out transglycosylation, whereby they transfer galactose residues to lactose acceptors to synthesise galactooligosaccharides (GOS) with various linkages and degrees of polymerisation (Reuter et al. 1999; Torres et al. 2010). Several in vitro and in vivo studies have shown that GOS selectively stimulates the growth of beneficial Bifidobacteria and Lactobacillus species in the gut (Torres et al. 2010; Walton et al. 2012), which is a valuable characteristic for infant milk formulas. Furthermore, GOS administered together with bacteria such as Bifidobacterium (synbiotics) (Gibson and Roberfroid 1995) can promote proliferation of these exogenously supplemented probiotics (Kolida and Gibson 2011). Thus, the biotechnological applications of $\beta$-galactosidases encompass production of lactosefree dairy products and production of GOS with prebiotic properties.

Commercially used $\beta$-galactosidases are most commonly obtained from Kluveromyces spp. and Aspergillus spp. However, these $\beta$-galactosidases have some undesirable properties, such as a low affinity for lactose and product inhibition by galactose at low $K_{i}$ (Erich et al. 2015). There is a need for the discovery of novel $\beta$-galactosidases which do not have these characteristics. In addition, there is demand for novel $\beta$-galactosidases with wider ranges of thermal and $\mathrm{pH}$ stability to suit industrial downstream processes and that can synthesise GOS with different types of linkages and degrees of polymerisation.

Metagenomics has uncovered genomes of uncultivated microorganisms from untapped environments leading to the discovery of natural products and enzymes with unique properties (Simon and Daniel 2011). Through function-based and sequence-based screening of metagenomes from diverse habitats, such as marine sediments, compost, desert sand and hydrothermal vents, valuable enzymes for biotechnology, food and pharmaceutical industries have been identified, including lipases, proteases and glycoside hydrolases (Lee et al. 2004; Neveu et al. 2011; Uchiyama et al. 2013). Human gut microbiome metagenomic libraries have revealed novel glycoside hydrolases (Cecchini et al. 2013; Tasse et al. 2010) and $\beta$-galactosidases with unique thermo-tolerant and alkalinetolerant properties have been identified in environmental metagenomic libraries (Cheng et al. 2017; Liu et al. 2019; Wierzbicka-Woś et al. 2013; Zhang et al. 2013).

In this study, a human faecal metagenomic fosmid library was used to identify $\beta$-galactosidases by functional screening. Clones with $\beta$-galactosidase activity were sequenced and a $\beta$ galactosidase enzyme of Bifidobacterium adolescentis, BAD 1582, was identified, which we have named BgaC. The enzyme was recombinantly expressed with a hexahistidine tag, purified, and the properties of the expressed enzyme were characterised. BgaC exhibited efficient hydrolysis of lactose and transglycosylation activity to produce oligosaccharides at low concentrations of lactose. These properties make the enzyme an ideal candidate for large-scale enzymatic hydrolysis of lactose and synthesis of potential prebiotic oligosaccharides in dairy and pharmaceutical industries.

\section{Material and methods}

All chemicals were analytical grade and purchased from Sigma-Aldrich/Merck, unless otherwise stated.

\section{Bacterial strains, plasmids, fosmids and growth conditions}

The Escherichia coli strains, fosmids and plasmids used in this study are shown in the Electronic Supplementary Material, Table S1. E. coli strains were grown at $37{ }^{\circ} \mathrm{C}$ in LB agar and broth with aeration. Antibiotics were added at the following final concentrations: chloramphenicol (12.5 $\mu \mathrm{g} / \mathrm{ml})$ and ampicillin $(120 \mu \mathrm{g} / \mathrm{ml})$.

\section{Construction of human faecal metagenome library}

A human faecal microbiome metagenome library was constructed using the Copy Control Fosmid Library Production Kit with pCC1FOS Vector (Epicentre) according to the manufacturer's instructions (Agbavwe 2017). This kit utilises a strategy of cloning randomly sheared, end-repaired DNA. A healthy, 27-year-old, female volunteer, consuming a Western diet (omnivorous), provided a fresh faecal sample for this study. The volunteer did not take any antibiotics or other drugs known to influence the faecal microbiota within the 6-month period prior to the study. The stool sample was homogenised and large particles removed by centrifugation. Bacterial cells were physically separated from host cells by density gradient layering (Nycodenz Axis Shield 1002424) (Ford and Rickwood 1982). DNA from the bacterial cells was then isolated using conventional DNA extraction methods.

Representative community DNA of the faecal microbiome was purified, and sheared, and the fragments were endrepaired to produce 5 '-phosphorylated blunt ends. The desired size range (approximately $40 \mathrm{~kb}$ ) of end-repaired DNA was isolated using agarose gel electrophoresis and ligated to the pCC1FOS vector. The ligated DNA was packaged into lambda phage and introduced into $E$. coli $\mathrm{EPI} 300-\mathrm{T} 1^{\mathrm{R}}$. The infected E. coli $\mathrm{EPI} 300-\mathrm{T} 1^{\mathrm{R}}$ cells were plated on selective $\mathrm{LB}$ agar media and allowed to grow overnight. The clones which harboured the ligated fosmids were picked, induced to high copy number using L-arabinose auto induction solution, pooled to generate the human faecal microbiome metagenome library and stored in aliquots at $15 \%$ glycerol at $-80{ }^{\circ} \mathrm{C}$. 
These aliquots were used for targeted gene identification via function-based screening.

\section{Functional screening of putative $\beta$-galactosidase-encoding clones}

The human faecal microbiome metagenome library was screened for pink colonies expressing a functional $\beta$ galactosidase on MacConkey lactose agar. A vial of stock human faecal microbiome metagenome library was thawed on ice, and a serial dilution which provided approximately 500 colonies per plate was prepared in LB broth. One hundred microliters was plated on MacConkey agar supplemented with lactose, $\mathrm{Cm}$ and arabinose. $\beta$-Galactosidase-positive clones were identified based on their pink morphology while $\beta$-galactosidase-negative clones were colourless. Clones that appeared pink on the MacConkey agar were picked and streaked on LB agar containing $\mathrm{Cm}$, arabinose and the chromogenic substrate 5-bromo-4-chloro-3-indolyl- $\beta$ galactopyranoside $(\mathrm{X}-\mathrm{Gal})$ at final concentration of $40 \mu \mathrm{g}$ $\mathrm{ml}^{-1}$ for confirmatory test, and positive clones were identified by formation of blue colonies. The Miller assay (Miller 1972) with ONPG substrate was conducted on positive clones to determine the $\beta$-galactosidase activity of the positive fosmid clones.

\section{Bioinformatic analysis}

Fosmids from $\beta$-galactosidase positive clones were prepared using the Qiagen plasmid preparation kit. Fosmid DNA was single- or double-digested with BamHI and SmaI (Thermo Fisher Scientific) and the restriction products were visualised using agarose gel electrophoresis. Clones that had distinct restriction patterns were end sequenced (Eurofins genomics). The forward and the reverse nucleotide sequences generated from end sequencing reactions of clones were analysed using Blast (https://blast.ncbi.nlm.nih.gov/Blast.cgi). Conserved domain databases (CDD) and Pfam were used to identify the conserved protein regions. Smart BLAST and ConstraintBased Multiple Alignment Tool (COBALT) (Papadopoulos and Agarwala 2007) were used to identify homologues with the landmark sequences. In addition, PSORTb subcellular localisation tool was implemented to predict subcellular protein localisation (Yu et al. 2010). Homology-based structure prediction was done using SWISS-MODEL (https:// swissmodel.expasy.org/).

\section{Cloning of identified $\beta$-galactosidase bgaC gene of $B$. adolescentis}

The $\beta$-galactosidase $B A D \_1582(\mathrm{bgaC})$ gene sequence of $B$. adolescentis ATCC 15703 was used to design cloning primers for PCR (CACCATGGCAGATACAGCCG
AACTC and GAACAGCTTGAGCTGAACGTTGAG). With fosmid clone 31 as template, Velocity DNA polymerase (Bioline) was used to generate a blunt end product ( 25 cycles: $30 \mathrm{~s}$ at $98^{\circ} \mathrm{C}, 30 \mathrm{~s}$ at $63{ }^{\circ} \mathrm{C}, 1 \mathrm{~min}$ and $30 \mathrm{~s}$ at $72{ }^{\circ} \mathrm{C}$ ). PCR products were isolated by DNA gel purification using Promega Wizard R SV gel and PCR clean-up system following the manufacturer's instructions. The purified blunt end DNA was cloned into expression plasmid pET101 (Invitrogen) following the directional cloning kit protocol. pET101 harbouring the $b g a C$ gene was transformed into the expression host E. coli $\mathrm{T} 7$ express lac $\mathrm{Z}^{-}$cells (Qin et al. 2010); the resulting clone was named $E$. coli T7express (pDMg1a). The primers ACGTATGCCTCGAATCG and CATATTTGGATAGCTC were used to determine the presence of $b g a C$ in fosmids by PCR using Taq DNA polymerase (Bioline), followed by visualisation of the PCR products by agarose gel electrophoresis.

\section{Expression and purification of BAD_1582}

E. coli $\mathrm{T} 7$ Express (pDMg1a) was grown to mid-log phase $\left(\mathrm{OD}_{600 \mathrm{~nm}}\right.$ between 0.4 and 0.7$)$. Isopropyl- $\beta$-D-thiogalactopyranoside (IPTG, $1 \mathrm{mM}$ ) was added and the culture was incubated for $4 \mathrm{~h}$ at $37^{\circ} \mathrm{C}$ to induce expression. An aliquot of the culture was then assayed for $\beta$-galactosidase activity using the Miller assay (Miller 1972). Cells were harvested by centrifugation and the pelleted cells were lysed with bug buster protein extraction reagent supplemented with $2 \mu \mathrm{l} / \mathrm{ml}$ lysozyme (Merck, USA). The lysate was centrifuged at $4{ }^{\circ} \mathrm{C}$ for $20 \mathrm{~min}$ at $16,000 \mathrm{~g}$, and the total cell lysate, the soluble fraction and the insoluble fractions were analysed by SDS-PAGE under denaturing condition to determine the localisation of the expressed enzyme. The soluble fraction containing the enzyme was then subjected to $\mathrm{Ni}^{2+}$-nitrilotriacetate $\left(\mathrm{Ni}^{2+}\right.$ NTA) affinity chromatography to purify the His-tagged enzyme (Thermo Fisher) according to the manufacturer's instruction.

The eluted fractions were concentrated and lower molecular mass proteins and imidazole removed using 100-kDa molecular weight cut-off (MWCO) Amicon Ultra-4 centrifugal filters (Merck, USA) and PBS buffer exchange. The retained protein (approximately $>100 \mathrm{kDa}$ ) concentration was determined by Bradford assay using bovine serum albumin (BSA) as standard. To determine the purity of the eluted fractions and the concentrated protein, SDS-PAGE was performed. After samples were electrophoresed on a $10 \%$ polyacrylamide gel, with broad range protein standards (11-245 $\mathrm{kDa})$, the gels were stained both with Coomassie Brilliant blue R 250 and silver stain (Conway et al. 2016) for visualisation of protein. The concentrated protein was stored in aliquots at $4{ }^{\circ} \mathrm{C}$ for immediate use, while for long-term storage $50 \%(\mathrm{v} / \mathrm{v})$ glycerol was added and stored at $-20{ }^{\circ} \mathrm{C}$. 


\section{Immunoblotting}

Proteins were separated by SDS-PAGE and transferred to a nitrocellulose membrane. The nitrocellulose membrane was washed with PBS, blocked with 5\% skim milk in PBS and probed using a monoclonal anti-polyhistidine antibody conjugated to horseradish peroxidase (1:2000 dilution) (Sigma). Visualisation was carried out by staining the nitrocellulose with tetramethylbenzidine (TMB) solution (Sigma) until sufficient colour was developed.

\section{$\beta$-Galactosidase activity assay}

All $\beta$-galactosidase activity assays (both hydrolysis and transglycosylation) were conducted with three independent biological replicates and the data presented are the means of the three experiments.

$\beta$-Galactosidase activity of the $\mathrm{BgaC}$ protein was determined using the chromogenic substrate ortho-nitrophenyl- $\beta$ D-galactopyranoside (ONPG) or lactose. The assay for ONPG was carried out in microtiter plates containing $8.75 \mathrm{mg} / \mathrm{ml}$ purified enzyme, $2 \mathrm{mM}$ ONPG in $50 \mathrm{mM}$ sodium phosphate buffer in a final volume of $100 \mu \mathrm{l}$, at $\mathrm{pH} 7.0$ and $37^{\circ} \mathrm{C}$ for 30 min. The reaction was stopped by addition of sodium carbonate to a final concentration of $500 \mathrm{mM}$. The hydrolysis product ortho-nitrophenol was detected by measuring absorbance at $420 \mathrm{~nm}$ (Biotek microplate spectrophotometer). A unit of an enzyme (1 U) is defined as the amount of the enzyme required to liberate $1 \mu \mathrm{mol}$ $o \mathrm{NP}$ from the ONPG substrate per minute in $50 \mathrm{mM}$ sodium phosphate buffer $(\mathrm{pH} 7.0)$ at $37^{\circ} \mathrm{C}$.

The assay for lactose hydrolysis was carried out with 89.5 $\mu \mathrm{g} / \mathrm{ml}$ purified enzyme and $5 \mathrm{mM}$ lactose in $50 \mathrm{mM}$ sodium phosphate buffer at $\mathrm{pH} 7.0$ and $37^{\circ} \mathrm{C}$ for $30 \mathrm{~min}$ and the enzyme was then inactivated by incubating at $95{ }^{\circ} \mathrm{C}$ for 5 min. The released glucose was quantified using a glucose oxidase/peroxidase assay kit (Sigma) and measuring absorbance at $540 \mathrm{~nm}$. A unit of enzyme (1 U) is defined as the amount of enzyme required to liberate $1 \mu \mathrm{mol}$ glucose from lactose per minute in $50 \mathrm{mM}$ sodium phosphate buffer at $\mathrm{pH} 7$ and at $37^{\circ} \mathrm{C}$.

\section{Effects of pH, temperature, divalent cations and denaturants/detergents on the activity and stability of BAD_1582}

The optimum $\mathrm{pH}$ of the enzyme was determined by using ONPG as a substrate in $50 \mathrm{mM}$ sodium phosphate buffer at $\mathrm{pH}$ ranges of 4.0 to 10.0 . The $\mathrm{pH}$ stability of the enzyme was determined by pre-incubating the enzyme in $50 \mathrm{mM}$ sodium phosphate buffer set at $\mathrm{pH} 4.0-10.0$ for $24 \mathrm{~h}$ at $4{ }^{\circ} \mathrm{C}$. The $\mathrm{pH}$ of the pre-incubated enzyme was adjusted to $\mathrm{pH} 7.0$ before the $\beta$-galactosidase activity was measured.
The effect of temperature on the enzyme activity was determined at different temperatures (from 0 to $60^{\circ} \mathrm{C}$ ) in $50 \mathrm{mM}$ sodium phosphate buffer at $\mathrm{pH} 7.0$. The temperature stability of the enzyme was determined by pre-incubating the enzyme in $50 \mathrm{mM}$ sodium phosphate buffer at the selected temperatures for $1 \mathrm{~h}$, after which the reactions were brought to $37^{\circ} \mathrm{C}$ and $\beta$-galactosidase activity was determined.

The effect of metal ions on the activity of the enzyme was determined at $\mathrm{pH}$ 7.0. The effect of $10 \mathrm{mM} \mathrm{K}^{+}(\mathrm{KCl})$ and $\mathrm{Mg}^{2+}\left(\mathrm{MgCl}_{2}\right)$ on enzyme activity was determined in $50 \mathrm{mM}$ sodium phosphate buffer. As most divalent cations precipitated in sodium phosphate buffer, $\mathrm{CaCl}_{2}, \mathrm{MgCl}_{2}$, $\mathrm{ZnCl}_{2}, \mathrm{FeCl}_{3}, \mathrm{CuSO}_{4}$ and $\mathrm{MnCl}_{2}$ at a final concentration of $10 \mathrm{mM}$ were dissolved in $100 \mathrm{mM}$ Tris- $\mathrm{HCl}$ buffer and enzyme activity determined in this buffer. To determine the effect of EDTA on the activity of BgaC, the enzyme was preincubated in $10 \mathrm{mM}$ EDTA in $50 \mathrm{mM}$ sodium phosphate buffer $\mathrm{pH} 7.0$ for $3 \mathrm{~h}$ at $4{ }^{\circ} \mathrm{C}$. Controls containing the same amount of enzyme incubated in sodium phosphate buffer containing $10 \mathrm{mM} \mathrm{MgCl}_{2}$ and enzyme in sodium phosphate buffer with no additional divalent metal ions were similarly prepared. Then, the $\beta$-galactosidase activity was determined.

The effects of detergents and denaturants on the activity of $\mathrm{BgaC}$ were determined by carrying out the $\beta$-galactosidase assay in $50 \mathrm{mM}$ sodium phosphate buffer supplemented with $10 \mathrm{mM} \mathrm{MgCl} 2 \mathrm{pH} 7.0$ and further supplemented with the following reagents: sodium dodecyl sulfate $(0.1,0.5$ and $1 \%)$, urea $(0.1,0.5$ and $1 \mathrm{M})$, Triton $\mathrm{X}-100(0.1,0.5$ and $1 \%)$ and $\beta$-mercaptoethanol $(1,10$ and $50 \mathrm{mM})$.

\section{Substrate specificity and kinetic parameters}

To determine the substrate specificity of the enzyme, different chromogenic nitrophenyl-based substrates with $\alpha$ - and $\beta$ linked sugars were used. $\mathrm{BgaC}$ was incubated with the nitrophenyl analogues at a final concentration of $2 \mathrm{mM}$ in $50 \mathrm{mM}$ sodium phosphate buffer $/ 10 \mathrm{mM} \mathrm{MgCl}$ at $\mathrm{pH} 7.0$ and $37^{\circ} \mathrm{C}$ and its hydrolytic activity was measured by absorbance at 420 $\mathrm{nm}$. The nitrophenyl substrates used were $p$ NP- $\beta$-Dgalactopyranoside ( $p$ NPG), $p$ NP- $\beta$-D-glucopyranoside ( $p$ NP- $\beta$-D-Glc), $p$ NP- $\alpha$-D-galactopyranoside ( $p$ NP- $\alpha$-D-Gal), $p$ NP- $\alpha$-D-mannopyranoside ( $p$ NP- $\alpha$-D-Man), $p$ NP- $\alpha$-Lfucopyranoside ( $p$ NP- $\alpha-\mathrm{L}-\mathrm{Fuc}$ ) (Toronto Research Chemicals, TRC), $p$ NP- $\alpha$-L-xylopyranoside (pNP- $\alpha$-L-Xyl) (TRC), $p$ NP-2-acetamido-2-deoxy- $\beta$-D-galactopyranoside $(p$ NP- $\beta$-D-GalNAc)(TRC) and $p$ NP-2-acetamido-2-deoxy- $\beta$ D-glucopyranoside ( $p$ NP-GlcNAc) (Carbosynth) and ONPG.

The kinetic parameters of $\mathrm{BgaC}$ were determined by measuring activity at different concentrations of ONPG $(0.25,0.5$, $0.75,1,2.5,5,10$ and $20 \mathrm{mM})$ and lactose $(5,10,25,50,100$ and $200 \mathrm{mM}$ ) in $50 \mathrm{mM}$ sodium phosphate buffer $\mathrm{pH} 7.0$ at 37 ${ }^{\circ} \mathrm{C}$ in a time course discontinuous enzyme assay monitored for $20 \mathrm{~min}$. Aliquots were withdrawn at 2-min intervals. For the 
ONPG assay, the aliquots were mixed with $500 \mathrm{mM}$ sodium carbonate to stop the reaction and absorbance at $420 \mathrm{~nm}$ was recorded, and for the lactose assay aliquots were incubated at $95^{\circ} \mathrm{C}$ for 5 min to inactivate the enzyme, and the glucose oxidase/peroxidase assay kit was used to determine the amount of glucose liberated. $V_{\max }$ and $K_{m}$ were calculated using the enzyme kinetics module tool of SigmaPlot software version 14.0 (Systat Software, San Jose, CA) from initial velocity versus substrate concentration plot. Both MichaelisMenten kinetics and Lineweaver-Burke plot transformation were implemented to determine $V_{\max }$ and $K_{m}$.

\section{Inhibition assays using lactose, galactose and glucose}

The $\beta$-galactosidase activity of $\mathrm{BgaC}$ was determined in the presence of lactose $(0.25-75 \mathrm{mM})$, Gal and Glc $(5-700 \mathrm{mM})$ as potential inhibitors and $1 \mathrm{mM}$ ONPG as substrate. The $K_{i}$ of lactose or $\mathrm{Gal}$ on $\mathrm{BgaC}$ activity was determined from the progress curves of the time course assay by applying competitive inhibition kinetics using Sigma Plot enzyme kinetic module.

\section{Transglycosylation activity assay}

Transglycosylation assays were carried out using 1.5 units $/ \mathrm{ml}$ BgaC enzyme in $50 \mathrm{mM}$ sodium phosphate buffer $/ 10 \mathrm{mM}$ $\mathrm{MgCl}_{2}$ at $37^{\circ} \mathrm{C}$ at $\mathrm{pH} 7.0$ for $24 \mathrm{~h}$. The first reaction set used $p$ NPG as galactosyl donor and various sugars as acceptors: fructose (Fru), L-arabinose (Ara), GlcNAc, Gal, Glc and lactose. The assay contained $100 \mathrm{mM} p \mathrm{NPG}(25 \mathrm{mM} p \mathrm{NPG}$ when lactose was used as acceptor) and $200 \mathrm{mM}$ acceptor sugar. In the second reaction set, $234 \mathrm{mM}$ lactose was used both as a galactosyl donor and an acceptor. In the third reaction set, $200 \mathrm{mM}$ lactose was used as a galactosyl donor and $100 \mathrm{mM}$ L-fucose or $\mathrm{N}$-acetylneuraminic acid (Neu5Ac) was used as an acceptor. After 24-h incubation, the enzyme was inactivated by heating at $95{ }^{\circ} \mathrm{C}$ for $5 \mathrm{~min}$. Transglycosylation products were also monitored in a time-dependent assay, containing $234 \mathrm{mM}$ lactose in $50 \mathrm{mM}$ sodium phosphate buffer $(\mathrm{pH} 7.0)$ and $1.5 \mathrm{unit} / \mathrm{ml}$ enzyme at $37{ }^{\circ} \mathrm{C}$ for $72 \mathrm{~h}$. Aliquot were withdrawn at 4, 8, 24, 48 and $72 \mathrm{~h}$.

Samples were analysed using TLC with silica gel 60G F 254 glass/aluminium foil plates as stationary phase. Samples and standards $(1 \mu \mathrm{l})$ were spotted on the plates and the plates were immersed on a mobile phase of n-propanol:distilled water:ethyl acetate $(7: 2: 1 \mathrm{v} / \mathrm{v} / \mathrm{v})$. The standard sugars were prepared in $50 \mathrm{mM}$ sodium phosphate buffer ( $\mathrm{pH} 7.0$ ) at same concentration as in transglycosylation assays: GOS (Carbosynth), GOS (Teagasc) (8\%), and lactose, Glc, Gal, Fru, L-Ara, GlcNAc, L-fucose, Neu5Ac and $p$ NPG $(75$ $\mathrm{mM})$. After separation, TLC plates were sprayed with $10 \%$ sulfuric acid in ethanol, allowed to completely dry and then charred at $105^{\circ} \mathrm{C}$ for $5 \mathrm{~min}$ to visualise carbohydrates (so $p \mathrm{NP}$ would not be visualised with this method). $R_{f}$ values for each spot of transglycosylation product were calculated by taking the ratio of distance travelled by each spot to distance travelled to solvent front and compared to the $R_{f}$ values of the standard sugars.

\section{High-performance liquid chromatography}

One milligram of each lyophilised sample obtained from transglycosylation reactions and $1 \mathrm{mg}$ each of lactose and standard GOS were labelled with $50 \mu$ labelling reagent per reaction ( $0.35 \mathrm{M}$ 2-aminobenzamide (2-AB), $1 \mathrm{M}$ sodium cyanoborohydride $\left(\mathrm{NaCNBH}_{3}\right)$ dissolved in $30 \%$ acetic acid in DMSO) in amber tubes (Bigge et al. 1995). Labelling reactions were incubated in the dark at $65{ }^{\circ} \mathrm{C}$ for $2.5 \mathrm{~h}$ with gentle shaking at $200 \mathrm{rpm}$ and samples were subsequently protected from light. Labelled samples were purified using Glycoclean S cartridges (ProZyme) following the manufacturer's instructions and dried by centrifugal evaporation. Samples were reconstituted in $100 \mu \mathrm{l}$ high-performance liquid chromatography (HPLC)-grade water and a 1:10 dilution of each sample was prepared. The diluted samples $(10 \mu \mathrm{l})$ were injected onto a GlycoSep N-Plus HPLC column (PROzyme) equipped with a guard column on a Waters Alliance 2695 system (Waters, MA, USA) and separated at column temperature of $30{ }^{\circ} \mathrm{C}$ using gradient elution. The mobile phase consisted of HPLC-grade acetonitrile (A) and $50 \mathrm{mM}$ ammonium formate, pH 4.4 (B), and the gradient started at $80 \%$ A to $47 \%$ A over $47.5 \mathrm{~min}$, held at $47 \%$ for $1 \mathrm{~min}$, changed to $0 \% \mathrm{~A}$ for $3 \mathrm{~min}$ to wash the column and then returned to $80 \%$ A over $1 \mathrm{~min}$ to reequilibrate for $13 \mathrm{~min}$ before the next injection, all at a flow rate of $0.667 \mathrm{ml} / \mathrm{min}$. Elution fluorescence was monitored at $\lambda_{\mathrm{ex}} 330 \mathrm{~nm}$ and $\lambda_{\mathrm{em}} 420 \mathrm{~nm}$ on a Waters 474 fluorescence detector.

\section{Statistical analysis}

All experiments were conducted with three independent biological replicates and graphs were plotted from the mean of the three experiments. Error bars in figures represent the standard deviation (SD) (mean $\pm \mathrm{SD}$ ). Statistical significance was determined by Student's $t$ test, and significance was represented with $p$ values $<0.001=* * *,<0.01=* *$ and $<0.05=*$.

\section{Results}

\section{Construction of metagenomic library}

A human faecal microbiome metagenomic library with insert sizes of $30-40 \mathrm{~kb}$ was constructed using the Copy ControlFosmid Library Production system. Forty-two thousand distinct clones were generated for the human faecal microbiome 
metagenomic library. To assess the diversity of the library, 15 random clones were analysed by restriction pattern analysis and end sequencing of the fosmid inserts. Ten (67\%) harboured different fragments of DNA originating from $B$. adolescentis both in the forward ( $5^{\prime}$ end of inserts) and reverse ( $3^{\prime}$ end of inserts) sequences with identities of 95$100 \%$ for most of the clones. However, clone 1 matched B. adolescentis with $77 \%$ identity and $95 \%$ identity for the forward and reverse sequences, respectively. One clone, clone 12, had a DNA fragment that originated from Bacteriodes fragilis (99\% and 100\% identity of forward and reverse sequence, respectively). Two clones matched Gordonibacter pamelaeae with $80 \%$ identity (clone 10) and Collinsella aerofaciens with $94 \%$ identity (clone 13) on reverse and forward sequences, respectively, but no significant similarity was found on the forward and reverse sequences, respectively, of these two clones. On the other hand, clone 9 had similarity with a different bacterial species at each end of the insert. The forward sequence of clone 9 had similarity with Bifidobacterium bifidum (83\% identity) while the reverse sequence had a match with Olsenella uli (73\% identity). Thus, the clones were distinct amongst themselves and some of them had either low or no significant similarity in the database, indicating the origin of DNA from these clones could be from previously uncharacterised members of the microbiome. Having established the genetic diversity of the library, it was then used for functional screening for $\beta$-galactosidases.

\section{Functional screening for $\boldsymbol{\beta}$-galactosidases in the human faecal microbiome metagenomic library}

Sixteen thousand clones were screened for $\beta$-galactosidase activity using MacConkey lactose agar. Clones expressing active $\beta$-galactosidase appeared pink, as the acidic fermentation products from lactose utilisation changed the colour of the $\mathrm{pH}$ indicator within the agar. The control lacZ E. coli EPI300 (pCC1FOS) appeared colourless, as did clones without active $\beta$-galactosidase. Thirty-two $\beta$-galactosidase-positive clones were identified (Electronic Supplementary Material, Fig. S1a). When streaked individually on MacConkey lactose agar, they showed strong lactose hydrolysis, even compared to lacZ positive E. coli BL21 (DE3), whereas the negative control E. coli EPI300 (pCC1FOS) displayed no colour change (Electronic Supplementary Material, Fig. S1b). $\beta$ Galactosidase activity was confirmed using LB agar supplemented with X-Gal for thirty clones, which formed characteristic blue colonies resulting from X-Gal hydrolysis. The positive control E. coli BL21 (DE3) also formed blue colonies while the negative control host strain did not (Electronic Supplementary Material, Fig. S1c).

Fosmids were prepared from each of the $30 \beta$ galactosidase-positive clones and were characterised by restriction pattern to identify distinct clones. Seven distinct clones were identified from the comparison of restriction patterns and subsequent analyses focused on one representative of each. The Miller assay was conducted on these clones using ONPG as a substrate, and high $\beta$-galactosidase activity (6005,795 Miller units) was detected, while the negative control E. coli EPI 300 (pCC1FOS) had low activity (36 Miller units).

\section{Bioinformatic analysis to identify $\beta$-galactosidase gene (BAD_1582) from human faecal microbiome metagenome clones}

The seven distinct fosmids were sequenced to generate the $5^{\prime}$ and $3^{\prime}$ sequences of their inserts using primers complimentary to $\mathrm{pCC} 1 \mathrm{FOS}$. Nucleotide blast searches established the origin of the DNA and indicated that the fosmid sequences had high identity (98-99\%) with genomic DNA of B. adolescentis, a common inhabitant of the adult human gut. One of these insert sequences had similarity with $B$. adolescentis only at the $3^{\prime}$ end and matched with an extrachromosomal DNA sequence ( $85 \%$ identity) at the $5^{\prime}$ end. The B. adolescentis strain from which this DNA fragment originated could have acquired the insertion sequences by horizontal transfer. The genome annotation of B. adolescentis ATCC15703 (NCBI) was used to identify possible $\beta$-galactosidase genes within the fosmid inserts. The gene map shows the regions of $B$. adolescentis genomic DNA contained within each fosmid (Fig. 1). All the clones shared the $\beta$-galactosidase $B A D \_1582$ gene and the adjacent five $B A D \_1583$ to $B A D \_1587$ genes. The adjacent genes encoded a sugar transporting permease, required by many bacteria to access sugars for adaptable growth in the gut environment. $B A D \_1582$-specific PCR, using the fosmids from the thirty $\beta$-galactosidase-positive clones as template, demonstrated that all fosmids possessed $B A D \_1582$, with the exception of clone 2 (Electronic Supplementary Material, Fig. S2a, b).

Through bioinformatic analysis, BAD_1582 was identified as a GH2 hydrolase with a homo-dimer structure. Bifidobacterium spp. protein sequences homologous to BAD_1582 (E-value $=0, \%$ identity $>68 \%)$ and the 5 SmartBLAST reference landmark amino acid sequences for known GH2 $\beta$-galactosidases (E-value $<\mathrm{e}^{-113}, \%$ identity $>$ $30 \%$ ) were phylogenetically analysed. BAD_1582 is distantly related to $\mathrm{GH} 2 \beta$-galactosidases identified from different species of bacteria and plants: Arabidopsis thaliana (30\% identity), soybean (32\% identity) Streptomyces coelicolor (40\% identity), Thermotoga maritima (33\% identity), E. coli (32\% identity). However, BAD_1582 is closely related to a $\beta$ galactosidase identified in several Bifidobacterium species: B. ruminatium ( $88 \%$ identity), B. pseudocatenulatum ( $77 \%$ identity), Bifidobacterium spp., N4GO5 (68\% identity), $B$. kashiwanohense (68\% identity), B. tsurumiense (68\% identity), B. catenulatum (68\% identity) and B. longum ( $68 \%$ identity), which indicates that these enzymes might be descended 


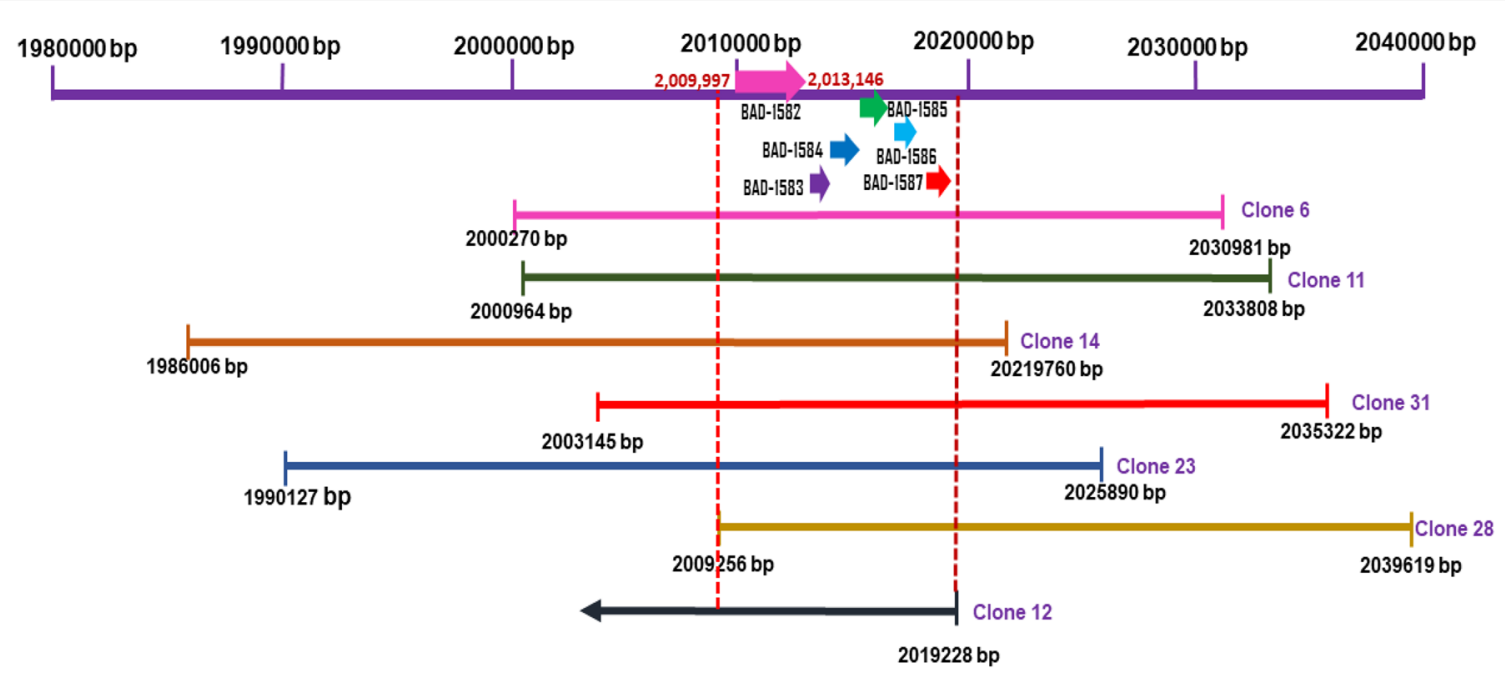

Fig. 1 Gene map of fosmids which incorporated regions of the $B$. adolescentis genome and their six shared genes. These include the $\beta$-galactosidase gene (BAD_1582, bgaC), HdeD family acid-resistance protein (BAD_1583), LacI family transcriptional regulator (BAD_1584), carbohydrate $\mathrm{ABC}$ transporter substrate-binding protein (BAD_1585),

from the same ancestral protein (Electronic Supplementary Material, Fig. S3). In contrast, BAD_1582 has much lower homology to $\beta$-galactosidases from $\bar{B}$. animalis, $B$. infantis, $B$. bifidum, $B$. breve, $B$. dentium, $B$. reuteri and other members of the Bifidobacterium taxon.

\section{Expression and purification of the $\beta$-galactosidase BAD_1582/BgaC}

The $\beta$-galactosidase $B A D \_1582$ gene was cloned with a hexahistidine tag in the pET101 vector and transformed into the lac $\mathrm{Z}^{-}$expression host $E$. coli $\mathrm{T} 7$ express. In order to express the recombinant BAD_1582, E. coli T7 express (pDMg1a) was cultured to exponential phase, $1 \mathrm{mM}$ IPTG was added and induction of protein expression was continued for $4 \mathrm{~h}$. After induction, a Miller assay carried out on IPTGinduced cells confirmed that enzyme activity was retained upon incorporation of the His-tag. The molecular mass of the His-tagged recombinant $\mathrm{BgaC}$ was predicted to be $116.5 \mathrm{kDa}$ by amino acid content. IPTG-induced $E$. coli (pDMg1a) cells were harvested, and lysed, and the Histagged enzyme was purified from the soluble fraction by $\mathrm{Ni}^{2+}$-NTA column chromatography. Remaining low molecular mass co-purified contaminant proteins were removed by filtration through a $100-\mathrm{kDa}$ MWCO filter and the resulting approximately $120-\mathrm{kDa}$ protein was the only protein present by Coomassie- and silver-stained SDS-PAGE analysis (Fig. $2 \mathrm{a}, \mathrm{b})$. Immunoblotting to detect the His-tag confirmed that the $120-\mathrm{kD}$ purified protein was His-tagged BAD_1582 (Fig. $2 \mathrm{c})$. The purified BAD_1582 was proven to have $\beta$ galactosidase activity with ONPG as substrate (Fig. 3a) and was consequently named $\mathrm{BgaC}$, following the convention of the previous study of BgaB (BAD 1401) (Hinz et al. 2004). sugar ABC transporter permease (BAD_1586), and carbohydrate ABC transporter permease (BAD_1587). The numbers at the start and end of each clone show location of the nucleotide sequences on the ATCC15703 genome

\section{Biochemical properties of BgaC}

$\beta$-Galactosidase activity of $\mathrm{BgaC}$ was tested over the $\mathrm{pH}$ ranges of 4.5 to 10.0 with ONPG as substrate. The enzyme had an optimum $\mathrm{pH}$ of 7.0 and retained $60 \%$ of its activity between $\mathrm{pH} 6.0$ and 8.0 (Fig. 3a). BgaC was stable at all $\mathrm{pH}$ values tested, and $87 \%$ of its activity was retained at $\mathrm{pH} 4$ (Fig. 3a).

The optimum temperature of this enzyme was determined to be $37^{\circ} \mathrm{C}$, but it was active over a wide range of temperatures, retaining $60 \%$ of its activity between 20 and $45^{\circ} \mathrm{C}$ (Fig. $3 b)$. The residual enzyme activity after $1 \mathrm{~h}$ incubation at those temperatures showed that the enzyme was active up to $40{ }^{\circ} \mathrm{C}$ (65\% of its activity was retained) and its activity declined as temperatures increased (at $50{ }^{\circ} \mathrm{C}$ less than $20 \%$ activity retained) (Fig. 3b). Storage temperatures of $4{ }^{\circ} \mathrm{C}$ or $-20{ }^{\circ} \mathrm{C}$ after 24-h incubation did not affect the activity of the enzyme. On the other hand, storage at room temperature $\left(20^{\circ} \mathrm{C}\right)$ for $24-$ $\mathrm{h}$ incubation decreased the activity of this enzyme by $35 \%$ (Fig. 3c). The enzyme was stored at $4{ }^{\circ} \mathrm{C}$ for more than 5 weeks and its activity was not altered (data not shown), but for long-term storage $-20{ }^{\circ} \mathrm{C}$ in a $50 \%$ glycerol stock was used and the activity was unaffected.

EDTA inhibited the activity of the enzyme which indicated a reliance on a divalent cation. The addition of $\mathrm{Mg}^{2+}$ enhanced the activity of BgaC by $30 \%$, followed by $\mathrm{Ca}^{2+}$ and then $\mathrm{Zn}^{2+}$ (Table 1). On the other hand, activity was abolished by $\mathrm{Cu}^{2+}$ and showed $59 \%$ reduction in the presence of $\mathrm{Mn}^{2+}$ (Table 1).

As shown in Fig. 4a, the enzyme was severely inhibited by the addition of SDS at a concentration of $0.5 \%$ and above, whereas addition of urea at $0.1 \mathrm{mM}$ enhanced the activity of BAD 1582, while no inhibition or enhancement were observed at concentrations of $0.5 \mathrm{mM}$ and $1 \mathrm{mM}$. Triton $\mathrm{X}$ - 
100 enhanced activity at $0.5 \%$ and $1 \%$, and no inhibition was observed at $0.1 \%$. The presence of $\beta$-mercaptoethanol did not affect the activity of $\mathrm{BgaC}$ at the concentrations tested indicating the absence of disulphide bonds in the binding and catalytic region(s) of the enzyme.

\section{Substrate specificity and kinetic parameters}

BgaC demonstrated high specific activity on $p N P G$ and ONPG, with a higher specific activity towards $p$ NPG (112 $\mu \mathrm{mol} / \mathrm{min} / \mathrm{mg}$ ) compared to ONPG $(18 \mu \mathrm{mol} / \mathrm{min} / \mathrm{mg})$. The specificity of BgaC was assessed and no activity was detected on $\alpha$-linked Gal as in $p \mathrm{NP}-\alpha$-Gal. The enzyme did not hydrolyse any other tested $p$ NP-based substrates, which included $p$ NP- $\beta$-D-Glc, $p$ NP- $\alpha$-D-Man, $p$ NP- $\alpha$-L-Fuc, $p$ NP- $\alpha$ L-Xyl, $p$ NP- $\beta$-GalNAc and $p$ NP- $\beta$-GlcNAc, which demonstrates that this enzyme acted exclusively on terminal $\beta$ linked Gal residues.

$\beta$-Galactosidase activity was measured using different concentrations of ONPG $(0.25-20 \mathrm{mM})$ and lactose $(5-200 \mathrm{mM})$, and the enzyme rate $\left(\mu \mathrm{mol} \mathrm{min}{ }^{-1} \mathrm{mg}^{-1}\right.$ ) was calculated from non-linear regression fit model of substrate concentration versus enzyme rate, Michaelis-Menten plot (Electronic Supplementary Material, Fig. S4a, b). The enzyme had a $K_{m}$ of $2.5 \mathrm{mM}$ and $V_{\max }$ of $107 \mu \mathrm{mol} \mathrm{min} \mathrm{mg}^{-1}$ for ONPG and $K_{m}$ of $3.7 \mathrm{mM}$ and $V_{\max }$ of $22 \mu \mathrm{mol} \mathrm{min}{ }^{-1} \mathrm{mg}^{-1}$ for lactose.
Fig. 2 BgaC purification.

Purification of the protein analysed by SDS-PAGE of purification step samples. Flow through and eluates were from $\mathrm{Ni}^{2+}-\mathrm{NTA}$ column purification and concentrate is after $100 \mathrm{kDa}$ MWCO filtration. a

Coomassie-stained gel, $\mathbf{b}$ silver-stained gel, and $\mathbf{c}$ immunoblot with anti-polyhistidine antibody conjugated to peroxidase and TMB staining



b




Fig. 3 Effect of $\mathrm{pH}$ and temperature on BgaC. Effect of a $\mathrm{pH}$ and $\mathbf{b}$ temperature on $\beta$-galactosidase activity (squares) and stability (triangles) of BgaC in $50 \mathrm{mM}$ sodium phosphate buffer, relative to activity at $\mathrm{pH}$ 7.0 and $37^{\circ} \mathrm{C}$, respectively. c Effect of storage temperature on BgaC activity, relative to activity after $4{ }^{\circ} \mathrm{C}$ storage. Values are the mean \pm SD of three independent experiments

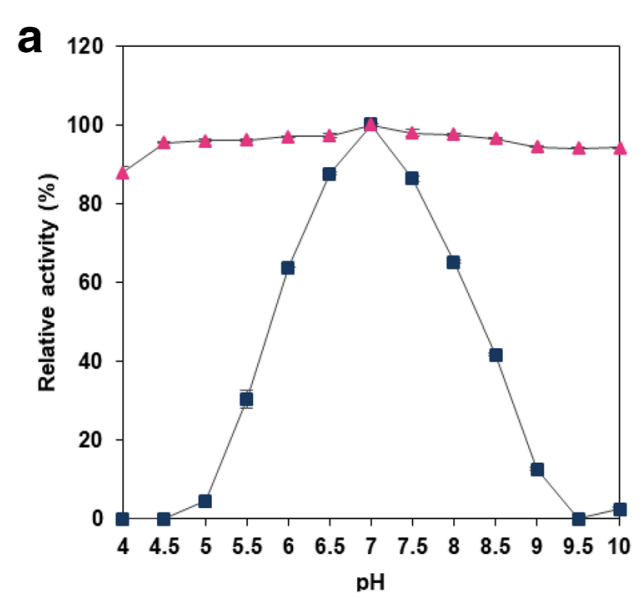

b
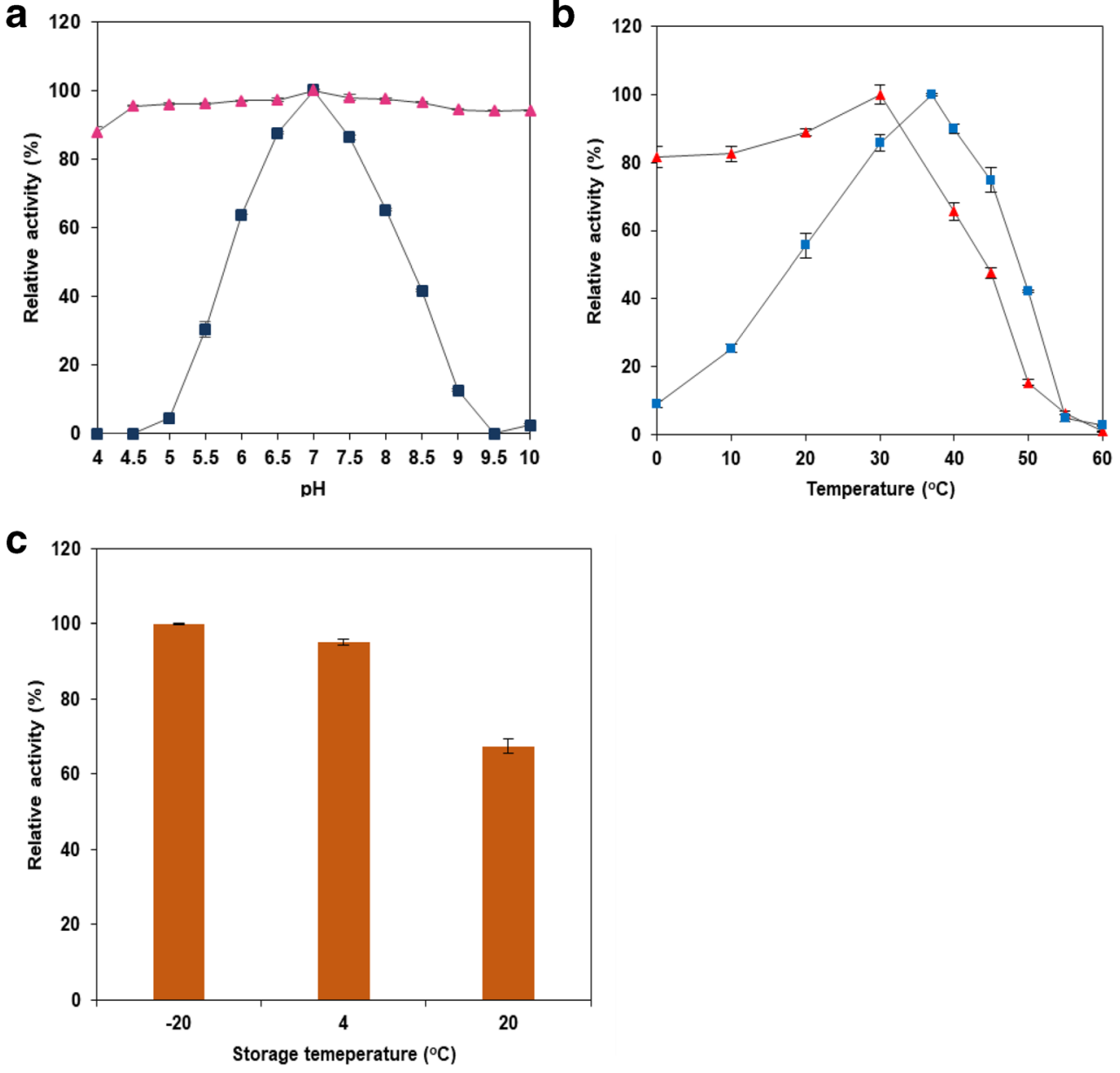

Besides, the catalytic efficiency, $K_{\mathrm{cat} /} K_{m}$, of this enzyme for ONPG was $84 \mathrm{~s}^{-1} \mathrm{mM}^{-1}$ which was 7-fold higher than that for lactose $\left(12 \mathrm{~s}^{-1} \mathrm{mM}^{-1}\right)$ (Table 2). Nevertheless, the rate of hydrolysis of ONPG showed a substantial decrease with increasing concentration of the chromogenic substrate ONPG $(\geq$

Table 1 Effect of divalent cations and EDTA on BgaC activity

\begin{tabular}{lll}
\hline Substance (10 mM) & $\begin{array}{l}\text { Relative activity (\%) } \\
\text { in phosphate buffer }\end{array}$ & $\begin{array}{l}\text { Relative activity (\%) } \\
\text { in } 100 \mathrm{mM} \text { Tris HCl }\end{array}$ \\
\hline $\mathrm{KCl}$ & $105 \pm 6$ & n.d \\
$\mathrm{MgCl}_{2}$ & $130 \pm 6$ & $174 \pm 4$ \\
$\mathrm{CaCl}_{2}$ & n.d & $141 \pm 4$ \\
$\mathrm{ZnCl}_{2}$ & n.d & $133 \pm 5$ \\
$\mathrm{MnCl}_{2}$ & n.d & $41 \pm 3$ \\
$\mathrm{CuSO}_{4}$ & n.d & $0 \pm 0$ \\
EDTA & $36 \pm 1$ & n.d \\
\hline
\end{tabular}

Values are mean \pm SD of three biological replicates, each with three technical replicates

${ }^{\text {a }}$ Relative to enzyme activity in absence of cations or EDTA

${ }^{\mathrm{b}}$ n.d not determined
$2.5 \mathrm{mM}$ ), but the enzyme did not display substrate inhibition when lactose was used as substrate. The $K_{i}$ of the enzyme for ONPG was $8 \mu \mathrm{M}$.

\section{Inhibition of BgaC by lactose, and tolerance to glucose and galactose}

The effect of different concentrations of lactose (substrate) and its hydrolysis products, glucose and galactose, on the activity of $\mathrm{BgaC}$ was examined in the presence of the synthetic substrate ONPG ( $1 \mathrm{mM}) . \beta$-Galactosidase activity towards ONPG declined markedly in the presence of increasing concentrations of lactose (Fig. 4b), suggesting that lactose is a competitive inhibitor to ONPG for binding to the enzyme active site. The $K_{i}$ of lactose as a competitive inhibitor was $100 \mu \mathrm{M}$. In addition, $K_{m}, V_{\max }$ and $K_{\text {cat }}$ in the presence of lactose as a competitive inhibitor were $0.7 \mathrm{mM}, 129 \mu \mathrm{mol}$ $\min ^{-1} \mathrm{mg}^{-1}$ and $250 \mathrm{~s}^{-1}$, respectively (Table 2 ). Thus, the catalytic efficiency $K_{\text {cat }} / K_{m}$ towards ONPG was low in the presence of lactose.

The effects of the hydrolytic products of lactose on the activity of the enzyme towards ONPG were also determined. The enzyme was highly tolerant to glucose, as $66 \%$ of the 
Fig. 4 Inhibition of BgaC. a Effect of detergents and denaturants on $\mathrm{BgaC}$ activity in $50 \mathrm{mM}$ sodium phosphate buffer. The data are relative to enzyme incubated in phosphate buffer/ 10 $\mathrm{mM} \mathrm{MgCl}{ }_{2}$ without detergent or denaturant. b Effect of lactose on BgaC activity on ONPG after 30min incubation. $\mathbf{c}$ Effect of Glc (squares) and $\mathrm{Gal}$ (triangles) on $\mathrm{BgaC}$ activity on ONPG after 30min incubation. Values are the mean $\pm \mathrm{SD}$ of three independent experiments a

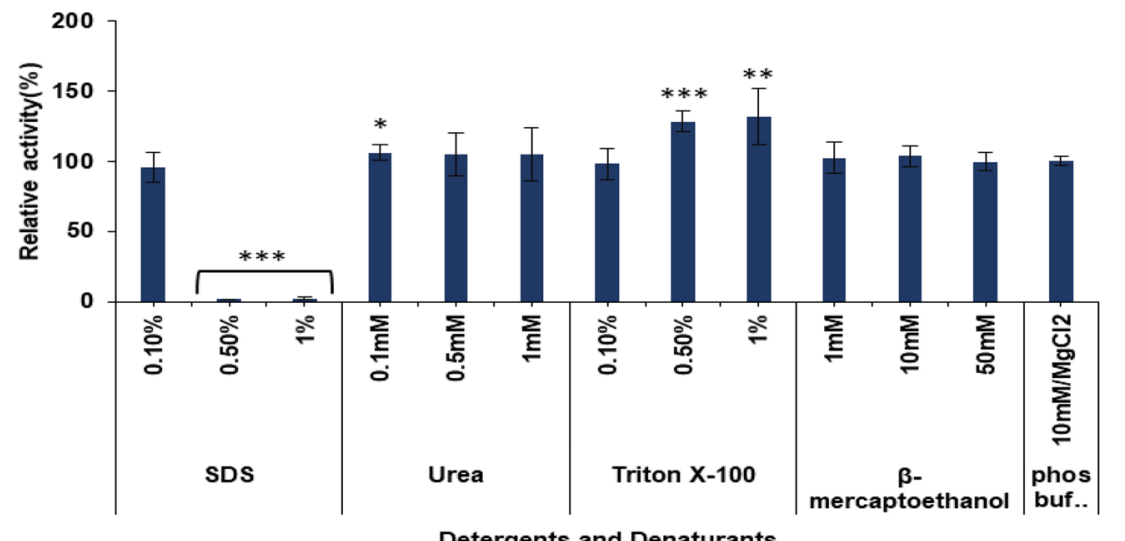

b

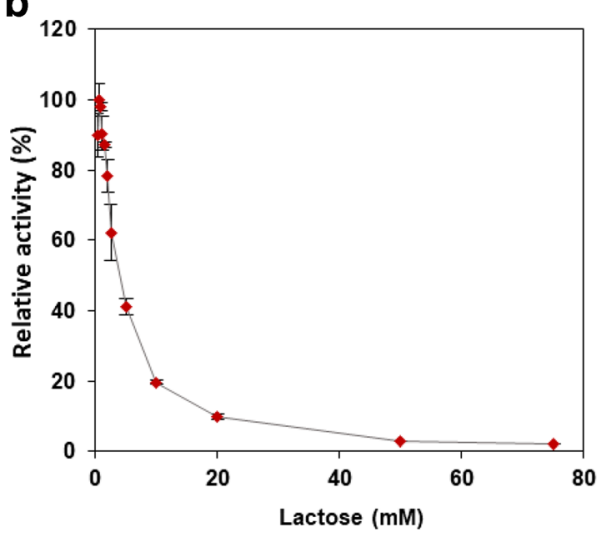

enzyme activity was retained even in the presence of $700 \mathrm{mM}$ glucose (Fig. 4c). However, it was observed that the enzyme was less tolerant to galactose and the activity of the enzyme decreased as the concentration of $\mathrm{Gal}$ increased above $100 \mathrm{mM}$ (Fig. 4c). About $44 \%$ of its relative activity was retained at $700 \mathrm{mM}$ Gal. The kinetic parameters of the enzyme towards ONPG in the presence of galactose as an inhibitor were determined. The $K_{i}, K_{m}, V_{\max }$ and $K_{\text {cat }}$ for Gal were $116 \mathrm{mM}, 1.0 \mathrm{mM}, 20 \mu \mathrm{mol} \mathrm{min}{ }^{-1} \mathrm{mg}^{-1}$ and $40 \mathrm{~s}^{-1}$, respectively (Table 2). Having a relatively high $K_{i}$ for Gal makes this enzyme an ideal candidate for its application in the enzymatic hydrolysis of lactose, due to its limited inhibition by its hydrolysis products.

\section{Transglycosylation activity and kinetics}

TLC was conducted to examine the hydrolysis and transglycosylation activity of BgaC. Gal was detected after cleavage of $p$ NPG after 24-h incubation as expected for the hydrolytic function of the $\beta$-galactosidase (Fig. 5a). To assess the transglycosylation activity of $\mathrm{BgaC}, p \mathrm{NPG}$ and lactose were used as galactosyl donors, and at 24-h transglycosylation occurred only in assays containing lactose as the donor and acceptor (Fig. 5b and Electronic Supplementary Material, Fig. S5 a-e and Fig. S6 a-c).

A kinetic study that examined products at incubation periods of 4, 8, 24, 48 and $72 \mathrm{~h}$ demonstrated that a lower degree

Table 2 Kinetic parameters of BgaC using ONPG and lactose as substrate, and in presence of lactose and Gal as competitive inhibitors of ONPG hydrolysis

\begin{tabular}{|c|c|c|c|c|c|}
\hline Substrate/inhibitor & $K_{\mathrm{m}}(\mathrm{mM})$ & $V_{\max }\left(\mu \mathrm{mol} \mathrm{min}{ }^{-1} \mathrm{mg}^{-1}\right)$ & $K_{\text {cat }}\left(\mathrm{s}^{-1}\right)$ & $K_{\mathrm{cat} /} K_{\mathrm{m}}\left(\mathrm{s}^{-1} \mathrm{mM}^{-1}\right)$ & $K_{i}(\mathrm{mM})$ \\
\hline ONPG & $2.5 \pm 1.3$ & $107 \pm 43$ & 209 & 84 & $0.0008 \pm 0.0004$ \\
\hline Lactose & $3.7 \pm 0.1$ & $22 \pm 1$ & 43 & 12 & $\mathrm{n} \cdot \mathrm{d}^{\mathrm{a}}$ \\
\hline $\mathrm{ONPG}+$ lactose $^{\mathrm{b}}$ & $0.7 \pm 0.004$ & $129 \pm 2$ & 250 & 357 & $0.1 \pm 0.003$ \\
\hline $\mathrm{ONPG}+\mathrm{Gal}$ & $1.0 \pm 0.004$ & $20 \pm 1$ & 40 & 40 & $116 \pm 5$ \\
\hline
\end{tabular}

${ }^{\text {a }}$ n.d no substrate inhibition observed and hence $K_{i}$ was not determined for lactose

${ }^{\mathrm{b}}$ ONPG $(1 \mathrm{mM})$ was used as substrate, lactose $(0.75-30 \mathrm{mM})$ and galactose $(10-700 \mathrm{mM})$ were used as inhibitors 
of polymerisation (DP) of oligosaccharide reaction products, presumably GOS, started to accumulate after $4 \mathrm{~h}$ of incubation (Fig. 5c). Hydrolytic products were also detected at this time point at a somewhat lesser intensity, suggesting that shorter transglycosylation products are favoured at this time point. The DP of the transglycosylation products increased over time up to the third sampling point $(24 \mathrm{~h})$ and maintained that DP until the final sampling time. After 72-h incubation, there was little remaining lactose and the hydrolysis reaction was clearly favoured over transglycosylation as Glc and Gal were the most intense reaction products (Fig. 5c). These results indicate a balance of reactions with transglycosylation and hydrolysis both occurring simultaneously at all time points, but the balance favouring different reaction products shifting over time.
HPLC analysis of the 2-AB labelled products of the transglycosylation reaction after $24 \mathrm{~h}$ confirmed that oligosaccharides (presumably galactooligosaccharides) with likely DP of 2 to 4 were produced by BgaC (Fig. 6(c, d)). Three individual trisaccharides (DP3) peaks and two distinct peaks of (DP4) were detected (Fig. 6(d)). Besides, three distinct disaccharides (DP2) were observed in Fig. 6(c), with the middle peak identified as lactose (compared to Fig. 6(a)). The other disaccharides produced were likely of different linkages compared to lactose and may have been of different monosaccharide composition (e.g. two Gal units compared to the Glc and Gal of lactose). The presence of multiple disaccharides in addition to the lactose reactant confirmed that $\mathrm{BgaC}$ could a

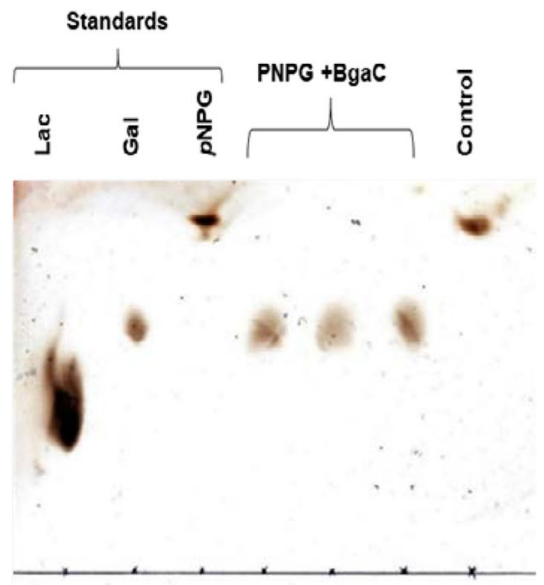

b



C
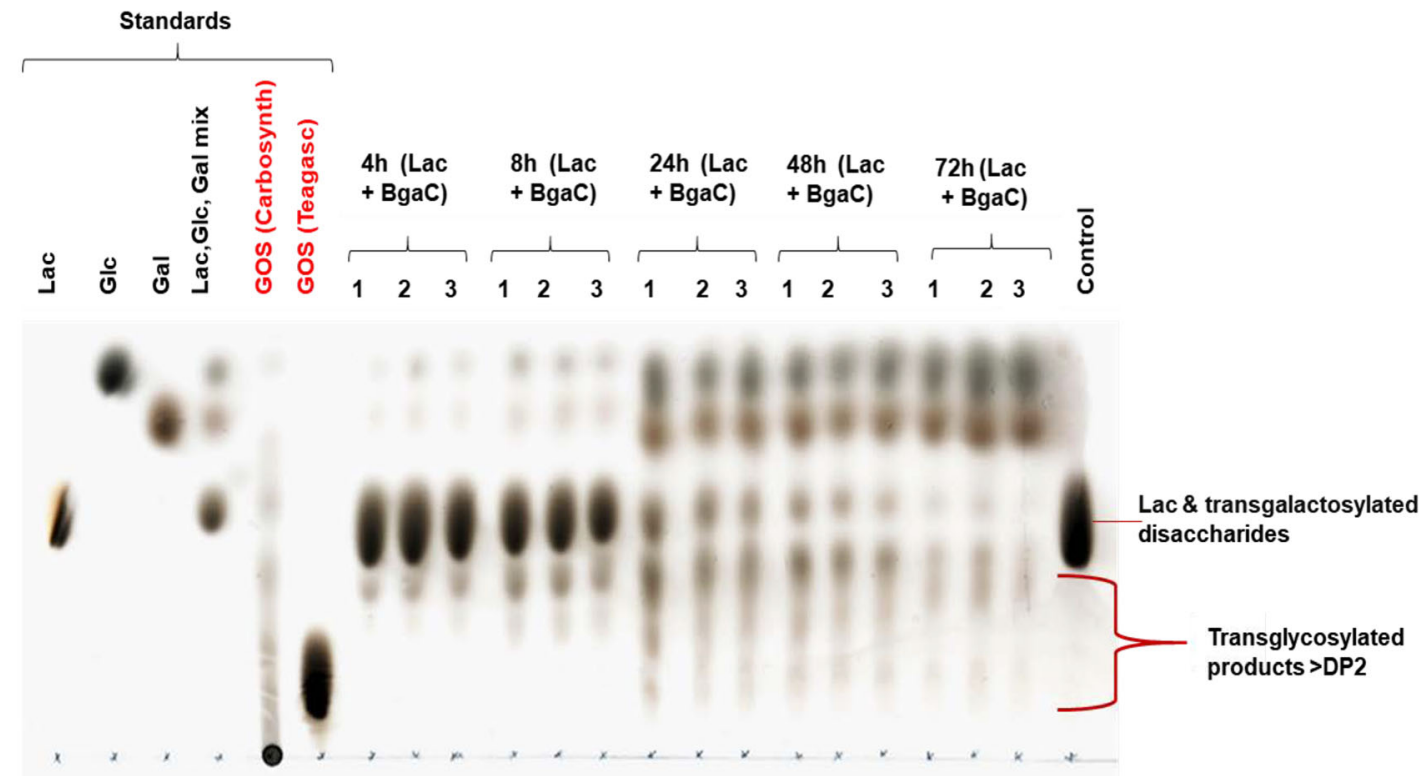

Fig. 5 TLC analysis of transglycosylation and hydrolysis activities of BgaC. a Hydrolysis of $p N P G$ after 24-h incubation. b Transglycosylation reaction products using lactose as donor and acceptor after 24-h incubation. c Kinetics of transglycosylation of BgaC using lactose as donor and acceptor, monitored between 4 and $72 \mathrm{~h}$ of incubation. Reactions with $1.5 \mathrm{unit} / \mathrm{ml} \mathrm{BgaC}$ enzyme were performed and analysed in triplicate. Control reactions were incubated without enzyme. Reactions were performed at $\mathrm{pH} 7$ and $37^{\circ} \mathrm{C}$ 
use not only lactose but also monosaccharides as acceptors for transglycosylation.

Reactions conducted using pNPG as the donor and either Gal or Glc as acceptors did not produce any transglycosylation products when analysed by TLC (Supplementary Figures S5a and $\mathrm{S} 5 \mathrm{~b}$ ), so it is possible that the released pNP was inhibitory to transglycosylation in these reactions. On the other hand, it may be that some lactose (or other disaccharide produced) must be present to favour transglycosylation using a monosaccharide acceptor or, more likely, that these disaccharides were the hydrolysis products from the DP3 and DP4 transglycosylation products, as hydrolysis continually occurs during these reactions. Thus, the HPLC analysis supports the earlier suggestion of hydrolysis of transglycosylation products from the time course reaction observation by TLC analysis (Fig. 5c).

Therefore, the $B$. adolescentis $\mathrm{BgaC} \beta$-galactosidase is a desirable enzyme for prebiotic manufacture and for application in dairy industries to produce lactose-free dairy products.

\section{Discussion}

In this study, through function-based screening of a human faecal microbiome metagenome library, a new $\beta$ galactosidase enzyme from $B$. adolescentis was identified.
Fig. 6 Chromatographs of transglycosylation and hydrolysis reactions of BgaC. (a)

Chromatograph of lactose standard (DP2). (b) Chromatograph of GOS standard (DP1 to $>5$ ). (c) $\mathrm{BgaC}$ reaction products after 24-h incubation, with reactants consisting of lactose $(234 \mathrm{mM})$ both as donor and as acceptor incubated at $37{ }^{\circ} \mathrm{C}$ with 1.5 unit $/ \mathrm{ml}$ enzyme at $\mathrm{pH}$ 7.0. (d) Inserted zoom of chromatograph (c) demonstrating $\mathrm{BgaC}$

transglycosylation products DP2 to DP4 a

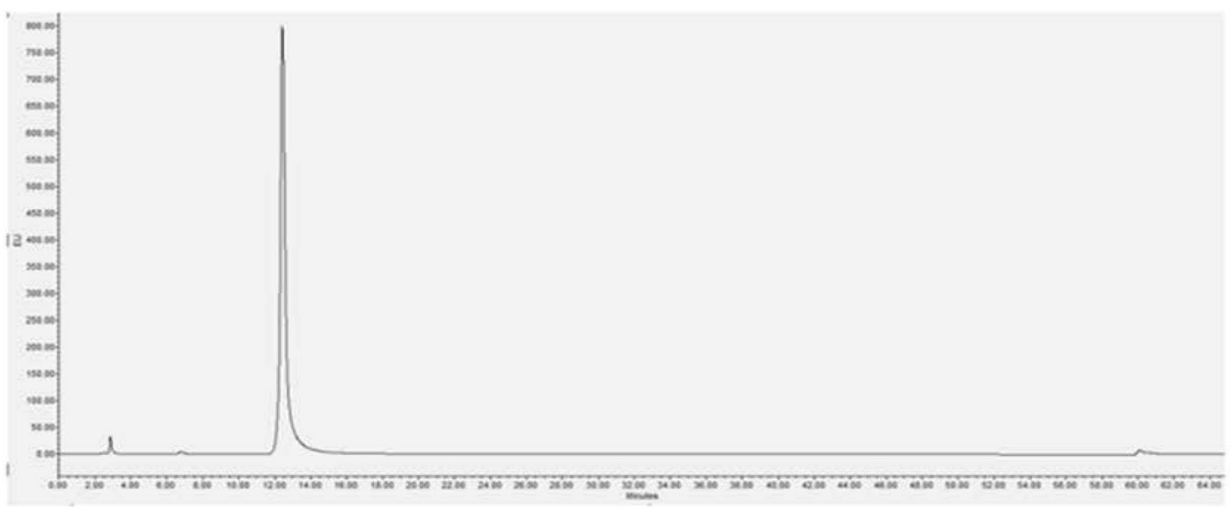

b

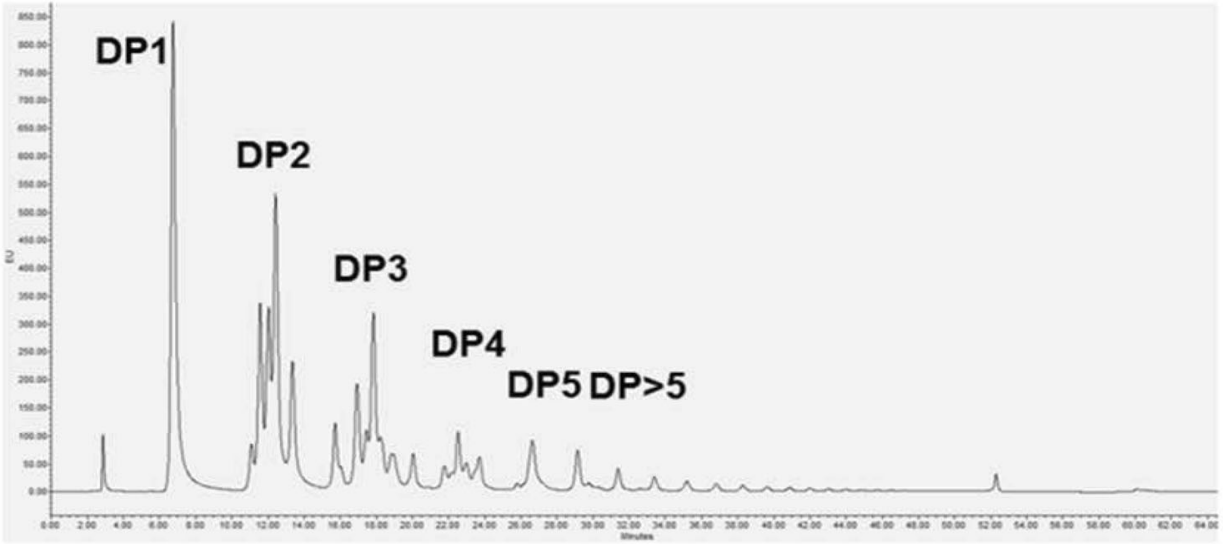

C



Time (min) 
BgaC possesses the industrially desirable properties of high substrate affinity for lactose and low product inhibition by Gal. Only a few $\beta$-galactosidases are used for food industry applications. The most widely used enzymes are obtained from Kluveromyces spp. and Aspergillus spp., as these source microbes are generally recognised as safe (GRAS) by the FDA (Adam et al. 2004). Even though these $\beta$ galactosidases have been widely utilised by dairy industries for removal of lactose and synthesis of GOS-based prebiotics, they have some limitations, such as low affinity for lactose and product inhibition by Gal (Erich et al. 2015). Thus, there is a demand for isolating new $\beta$-galactosidases that can surpass the aforementioned limitations.

Twenty-nine fosmids that had incorporated different regions of the genome of $B$. adolescentis harbouring $b g a C$ were selected through our agar-based functional screening. The high abundance of $B$. adolescentis in the adult human gut microbiomes (Milani et al. 2015a) likely explains the selection of a high number of clones containing $b g a C$. The $b g a C$ gene was identified as encoding a putative $\beta$-galactosidase during genome sequencing of this bacterium (Akiyama et al. 2015). Our phylogenetic analysis demonstrated that $\mathrm{BgaC}$ had strong evolutionary linkages with $\beta$-galactosidases from other species of Bifidobacterium, but these enzymes were not characterised. Some unrelated Bifidobacterium $\beta$ galactosidases have been isolated and characterised through expression of the recombinant enzyme in $E$. coli, and amongst these, a few displayed transglycosylation activity and synthesis of GOS (Arreola et al. 2014; Hsu et al. 2007; Oh et al. 2017; Yi et al. 2011).

$B A D \_1582$ is the first gene in a 6-gene sugar utilisation operon. BAD_1583 encodes a protein of unknown function with a predicted cytoplasmic N-terminal region followed by 6 transmembrane domains that have some similarity with the HdeD acid-resistance protein and the DUF308 memb families. BAD_1584 is a LacI-family transcription regulator. The archetypic LacI repressor controls transcription of the lac operon by binding to the operator sequence in the absence of lactose (Oehler 2009). Downstream are genes encoding an ABC transporter substrate-binding protein (BAD_1585), sugar $\mathrm{ABC}$ transporter permease (BAD_1586) and carbohydrate ABC transporter permease (BAD_1587) which together form a complex to transport sugars (possibly lactose and other oligosaccharides) into the cell. In addition, the genome of B. adolescentis encodes two LacS symporters (BAD_1188 and BAD 1604), which probably have an equivalent function to the lactose permease of $E$. coli, transporting lactose and cations simultaneously.

An abundant repertoire of glycosidases enables Bifidobacterium to be amongst the most successful colonisers of the human gut, and in addition inter-species cross-feeding has been implicated in their success (De Vuyst and Leroy
2011; Egan et al. 2014; Milani et al. 2015b; Turroni et al. 2018). The genome of $B$. adolescentis ATCC15703 encodes eight galactosidase enzymes (https://www.ncbi.nlm.nih.gov/ genome/proteins/683?genome_assembly_id=300284), of which two are $\alpha$-galactosidases (BAD_RS08025/1528 (GH36) and BAD RS08295/1576 (GH36)) and the remaining six are $\beta$-galactosidases (BAD_RS06400/1211 (GH42), BAD_RS07395/1401 (GH42) (Hinz et al. 2004; Van Laere et al. 2000), BAD RS07400/1402, BAD RS08435/1603 (GH42), BAD_RS08325/1582 (GH2) and BAD_RS08455/ 1605 (GH2)). Besides the galactosidases, the genome of $B$. adolescentis ATCC15703 encodes two lacS (lactose and galactose permease, GPH translocator family) genes (BAD RS05925/1188 and BAD_RS08450/1604), which are symporters for translocating sugars and solutes. The presence of a high number of galactosidase enzymes in the genome of this bacterium supports the existence of possible specialisation amongst these enzymes for various glycan substrates, such as the host mucin oligosaccharides or dietary fibres.

Although six or more $\beta$-galactosidase genes are present in genomes of $B$. adolescentis, only bgaC was selected from the function-based screening of our metagenome library. Possible reasons the other $B$. adolescentis $\beta$-galactosidases were not detected could be because they were not expressed by the heterologous host $E$. coli due to factors such as codon bias, difference in transcription factors, poor expression of molecular chaperones, toxicity of proteins (Boel et al. 2016; Lipinszki et al. 2018; Rosano and Ceccarelli 2014) or because they were not translocated to their functional destination by the $E$. coli secretory system, e. g. extracellular proteins (Baneyx 1999). B. adolescentis grown in a culture supplemented with GOS induced the production of various galactosidases and $\mathrm{BgaC}$ was amongst the significantly upregulated enzymes (Akiyama et al. 2015; Van Laere et al. 2000). The LacI family transcription regulator $B A D \_1584$ gene present in each of the fosmid clones (Fig. 2) presumably encodes a regulator controlling the transcription of the $b g a C$ operon (Oehler 2009), and thus BgaC was sufficiently expressed in the E. coli host.

Purified BgaC enzyme had optimal hydrolytic activity at $\mathrm{pH} 7.0$ and $37^{\circ} \mathrm{C}$ using ONPG as substrate. The hydrolytic activity of this enzyme at physiological $\mathrm{pH}$ and temperature is compatible with the bacterium's environment in the human gut. On the other hand, $B$. adolescentis $\beta$-gal II (BAD_RS07395/1582, GH2) has an optimal pH of 6.0 and temperature of $35^{\circ} \mathrm{C}$ using $p$ NPG as a substrate (Hinz et al. 2004). Thus, the various $B$. adolescentis $\beta$-galactosidases display different properties. Temporary fluctuations from a fruitrich diet, acidic secretions from the stomach or increased bile salts resulting from fermentation of dietary fibres by resident microbiota contribute to $\mathrm{pH}$ changes within the colon (Tomasello et al. 2016; Tomasello et al. 2014). The wide 
range of $\mathrm{pH}$ stability ( $\mathrm{pH} 4-10$ ) of $\mathrm{BgaC}$ would contribute to the $\mathrm{pH}$ adaptation of this beneficial bacterium.

$\mathrm{BgaC}$ displayed substrate specificity for $\beta$-linked Gal. Distinct flanking motifs in the active site of three GH42 $\beta$ galactosidase of $B$. longum affect their substrate specificities (Viborg et al. 2014). BgaC can hydrolyse lactose and $p$ NPG efficiently even though the catalytic efficiency was lower than for ONPG. A couple of GH2 and GH42 $\beta$-galactosidases isolated from Bifidobacterium species and metagenome clones showed a higher catalytic activity towards ONPG than lactose (Arreola et al. 2014; Yi et al. 2011; Zhang et al. 2013). Lactose is a preferred substrate for some GH1 and GH2 $\beta$ galactosidases (Adam et al. 2004), while some GH35 and GH42 $\beta$-galactosidases act on other $\beta$-linked Gal containing glycosides. This specialisation for different substrates may explain why $B$. adolescentis possesses six $\beta$-galactosidases.

One of the important properties required in industrial enzymes is their tolerance to product inhibition. BgaC displayed high tolerance to galactose $\left(K_{i}=116 \mathrm{mM}\right)$ and glucose (no inhibition detected). A couple of metagenome-derived $\beta$-galactosidases showing high tolerance to galactose with $K_{i}$ values of 197 and $238 \mathrm{mM}$ have been reported (Erich et al. 2015; Zhang et al. 2013). On the other hand, the hydrolytic activity of some $\beta$-galactosidases towards ONPG showed strong inhibition by galactose with low $K_{i}$; for instance, $B$. breve $\beta$-gal I and II have $K_{i}$ values of 15 and $34 \mathrm{mM}$, respectively (Arreola et al. 2014), and the Aspergillus oryzae $\beta$-galactosidase has a $K_{i}$ of $25 \mathrm{mM}$ (Vera et al. 2011). Having a high $K_{i}$ for galactose makes $\mathrm{BgaC}$ an ideal candidate to undertake enzymatic hydrolysis of lactose with low risk of product inhibition.

$\mathrm{BgaC}$ exhibited transglycosylation activity at a relatively low lactose concentration $(\sim 200 \mathrm{mM})$ compared to known and commercial $\beta$-galactosidases that require high lactose concentrations (40\% w/v or $1.17 \mathrm{M}$ ) (Guerrero et al. 2015; Hsu et al. 2007; Oh et al. 2017; Reuter et al. 1999). The ability of this enzyme to synthesise transglycosylation products, presumably GOS, could result in reduced GOS production costs using $\mathrm{BgaC}$ compared to currently available commercial enzymes. It is clear from the TLC and HPLC analysis that BgaC primarily produces oligosaccharides with DP2-4, exhibiting a narrower range and shorter length of oligosaccharide compared to commercial GOS. Depending on the prebiotic activity desired (e.g. certain beneficial bacterial species preferentially ferment oligosaccharides of specific lengths) (Garrido et al. 2013), this enzyme could be desirable to generate GOS with specific characteristics, either together with current enzymes or individually.

In the present work, the novel BgaC $\beta$-galactosidase enzyme from $B$. adolescentis was discovered from a human faecal microbiome metagenomic library. Its wide $\mathrm{pH}$ stability, stability at refrigeration storage conditions and high tolerance for Gal make it a desirable enzyme for the industrial application of removing lactose from dairy products. Furthermore, the transglycosylation activity of the enzyme demonstrates the potential for further utility in prebiotic manufacture. The successful discovery and expression of a functional $\beta$ galactosidase with valuable properties from a human faecal microbiome metagenomic library demonstrates that human in vivo microenvironments are a rich and important source of industrially useful enzymes.

Supplementary Information The online version contains supplementary material available at https://doi.org/10.1007/s00253-020-11084-y.

Acknowledgements We thank technical staff members Ms. Ann Smyth, Dr. Katrina Lacey, Mr. Mike Coughlan and Mr. Maurice Martyn, Discipline of Microbiology, NUI Galway, for the technical support. We are grateful to Dr. Maria Tuohy (NUI Galway) for providing access to instruments. We thank Glycom A/S, Hørsholm, Denmark, for kindly providing the HMOs used in this study.

Author contribution $\mathrm{AB}, \mathrm{COB}$ and $\mathrm{MK}$ conceived research plan, supervised research progress, critically evaluated experimental protocols and data and revised manuscript. DMM performed the experiments to identify, purify and characterise $\mathrm{BgaC}$. CA constructed faecal microbiome metagenome library. $\mathrm{BJ}$ and LA trained $\mathrm{CA}$ on metagenome library construction. MK conducted HPLC. AB and DMM wrote the manuscript. All authors read and approved the manuscript.

Funding DMM was supported by a NUI Galway College of Science PhD scholarship. CA was supported by the $\mathrm{PhD}$ programme "Molecular and Cellular Mechanisms Underlying Inflammatory Processes" funded by the Higher Education Authority of Ireland under Cycle 5 of the Irish Government's Programme for Research in Third Level Institutions (PRTLI).

Data availability Data and material for this article are available upon request.

\section{Compliance with ethical standards}

Conflict of interest The authors declare that they have no conflicts of interest.

Ethics for approval This article did not contain research involving humans or animals performed by any of the authors.

Consent to participate Not applicable

Consent for publication The authors have agreed upon the publication of this manuscript.

Code availability Not applicable

Open Access This article is licensed under a Creative Commons Attribution 4.0 International License, which permits use, sharing, adaptation, distribution and reproduction in any medium or format, as long as you give appropriate credit to the original author(s) and the source, provide a link to the Creative Commons licence, and indicate if changes were made. The images or other third party material in this article are included in the article's Creative Commons licence, unless indicated 
otherwise in a credit line to the material. If material is not included in the article's Creative Commons licence and your intended use is not permitted by statutory regulation or exceeds the permitted use, you will need to obtain permission directly from the copyright holder. To view a copy of this licence, visit http://creativecommons.org/licenses/by/4.0/.

\section{References}

Adam AC, Rubio-Texeira M, Polaina J (2004) Lactose: the milk sugar from a biotechnological perspective. Crit Rev Food Sci Nutr 44(78):553-557. https://doi.org/10.1080/10408690490931411

Agbavwe C (2017) Identification and characterisation of novel glycan binding bacterial adhesins encoded by the human gut microbial metagenome. $\mathrm{PhD}$ thesis, National University of Ireland, Galway

Akiyama T, Kimura K, Hatano H (2015) Diverse galactooligosaccharides consumption by bifidobacteria: implications of $\beta$-galactosidaseLacS operon. Biosci Biotechnol Biochem 79(4):664-672. https:// doi.org/10.1080/09168451.2014.987204

Arreola SL, Intanon M, Suljic J, Kittl R, Pham NH, Kosma P, Haltrich D, Nguyen T-H (2014) Two $\beta$-Galactosidases from the human isolate Bifidobacterium breve DSM 20213: molecular cloning and expression, biochemical characterization and synthesis of galactooligosaccharides. PLoS One 9(8):1-13. https://doi.org/10.1371/ journal.pone. 0104056

Baneyx F (1999) Recombinant protein expression in Escherichia coli. Curr Opin Biotechnol 10(5):411-421. https://doi.org/10.1016/ S0958-1669(99)00003-8

Bigge JC, Patel TP, Bruce JA, Goulding PN, Charles SM, Parekh RB (1995) Nonselective and efficient fluorescent labeling of glycans using 2-amino benzamide and anthranilic acid. Anal Biochem 230(2):229-238. https://doi.org/10.1006/abio.1995.1468

Boel G, Letso R, Neely H, Price WN, Wong KH, Su M, Luff J, Valecha M, Everett JK, Acton TB, Xiao R, Montelione GT, Aalberts DP, Hunt JF (2016) Codon influence on protein expression in $E$. coli correlates with mRNA levels. Nature 529(7586):358-363. https:// doi.org/10.1038/nature16509

Cecchini DA, Laville E, Laguerre S, Robe P, Leclerc M, Doré J, Henrissat B, Remaud-Siméon M, Monsan P, Potocki-Véronèse G (2013) Functional metagenomics reveals novel pathways of prebiotic breakdown by human gut bacteria. PLoS One 8(9):e72766. https://doi.org/10.1371/journal.pone.0072766

Cheng J, Romantsov T, Engel K, Doxey AC, Rose DR, Neufeld JD, Charles TC (2017) Functional metagenomics reveals novel $\beta$ galactosidases not predictable from gene sequences. PLoS One 12(3):e0172545. https://doi.org/10.1371/journal.pone.0172545

Conway JM, Pierce WS, Le JH, Harper GW, Wright JH, Tucker AL, Zurawski JV, Lee LL, Blumer-Schuette SE, Kelly RM (2016) Multidomain, surface layer-associated glycoside hydrolases contribute to plant polysaccharide degradation by caldicellulosiruptor species. J Biol Chem 291(13):6732-6747. https://doi.org/10.1074/jbc. M1 15.707810

De Vuyst L, Leroy F (2011) Cross-feeding between bifidobacteria and butyrate-producing colon bacteria explains bifdobacterial competitiveness, butyrate production, and gas production. Int J Food Microbiol 149(1):73-80. https://doi.org/10.1016/j.ijfoodmicro. 2011.03.003

Egan M, O'Connell Motherway M, Kilcoyne M, Kane M, Joshi L, Ventura M, van Sinderen D (2014) Cross-feeding by Bifidobacterium breve UCC2003 during co-cultivation with Bifidobacterium bifidum PRL2010 in a mucin-based medium. BMC Microbiol 14(1):282. https://doi.org/10.1186/s12866-0140282-7
Erich S, Kuschel B, Schwarz T, Ewert J, Bohmer N, Niehaus F, Eck J, Lutz-Wahl S, Stressler T, Fischer L (2015) Novel high-performance metagenome $\beta$-galactosidases for lactose hydrolysis in the dairy industry. J Biotechnol 210:27-37. https://doi.org/10.1016/j.jbiotec. 2015.06.411

Ford T, Rickwood D (1982) Formation of isotonic nycodenz gradients for cell separations. Anal Biochem 124(2):293-298

Gänzle MG, Haase G, Jelen P (2008) Lactose: crystallization, hydrolysis and value-added derivatives. Int Dairy J 18(7):685-694. https://doi. org/10.1016/j.idairyj.2008.03.003

Garrido D, Ruiz-Moyano S, Jimenez-Espinoza R, Eom H-J, Block DE, Mills DA (2013) Utilization of galactooligosaccharides by Bifidobacterium longum subsp. infantis isolates. Food Microbiol 33(2):262-270. https://doi.org/10.1016/j.fm.2012.10.003

Gibson GR, Roberfroid MB (1995) Dietary modulation of the human colonic microbiota: introducing the concept of prebiotics. J Nutr 125(6):1401-1412. https://doi.org/10.1093/jn/125.6.1401

Guerrero C, Vera C, Conejeros R, Illanes A (2015) Transgalactosylation and hydrolytic activities of commercial preparations of $\beta$ galactosidase for the synthesis of prebiotic carbohydrates. Enzym Microb Technol 70:9-17. https://doi.org/10.1016/j.enzmictec.2014. 12.006

Hinz SW, van den Brock LA, Beldman G, Vincken JP, Voragen AG (2004) $\beta$-galactosidase from Bifidobacterium adolescentis DSM20083 prefers $\beta(1,4)$-galactosides over lactose. App1 Microbiol Biotechnol 66(3):276-284. https://doi.org/10.1007/ s00253-004-1745-9

Hsu C-A, Lee S-L, Chou C-C (2007) Enzymatic production of galactooligosaccharides by $\beta$-galactosidase from Bifidobacterium longum BCRC 15708. J Agric Food Chem 55(6):2225-2230

Kolida S, Gibson GR (2011) Synbiotics in health and disease. Annu Rev Food Sci Technol 2:373-393. https://doi.org/10.1146/annurevfood-022510-133739

Lee SW, Won K, Lim HK, Kim JC, Choi GJ, Cho KY (2004) Screening for novel lipolytic enzymes from uncultured soil microorganisms. Appl Microbiol Biotechnol 65(6):720-726. https://doi.org/10.1007/ s00253-004-1722-3

Lipinszki Z, Vernyik V, Farago N, Sari T, Puskas LG, Blattner FR, Posfai G, Gyorfy Z (2018) Enhancing the translational capacity of E. coli by resolving the codon bias. ACS Synth Biol 7(11):2656-2664. https://doi.org/10.1021/acssynbio.8b00332

Liu P, Wang W, Zhao J, Wei D (2019) Screening novel $\beta$-galactosidases from a sequence-based metagenome and characterization of an alkaline $\beta$-galactosidase for the enzymatic synthesis of galactooligosaccharides. Protein Expr Purif 155:104-111. https://doi.org/ 10.1016/j.pep.2018.12.001

Lombard V, Golaconda Ramulu H, Drula E, Coutinho PM, Henrissat B (2014) The carbohydrate-active enzymes database (CAZy) in 2013. Nucleic Acids Res 42(Database issue):D490-D495. https://doi.org/ 10.1093/nar/gkt1178

Mawson AJ (1994) Bioconversions for whey utilization and waste abatement. Bioresour Technol 47(3):195-203. https://doi.org/10.1016/ 0960-8524(94)90180-5

Milani C, Lugli GA, Duranti S, Turroni F, Mancabelli L, Ferrario C, Mangifesta M, Hevia A, Viappiani A, Scholz M, Arioli S, Sanchez B, Lane J, Ward DV, Hickey R, Mora D, Segata N, Margolles A, van Sinderen D, Ventura M (2015a) Bifidobacteria exhibit social behavior through carbohydrate resource sharing in the gut. Sci Rep 5:15782. https://doi.org/10.1038/srep15782

Milani C, Mancabelli L, Lugli GA, Duranti S, Turroni F, Ferrario C, Mangifesta M, Viappiani A, Ferretti P, Gorfer V, Tett A, Segata $\mathrm{N}$, van Sinderen D, Ventura M (2015b) Exploring vertical transmission of bifidobacteria from mother to child. Appl Environ Microbiol 81(20):7078-7087. https://doi.org/10.1128/aem.02037-15

Miller J (1972) Experiments in molecular genetics. Cold Spring Harbor Laboratory Press, Cold Spring Harbor 
Neveu J, Regeard C, DuBow MS (2011) Isolation and characterization of two serine proteases from metagenomic libraries of the Gobi and Death Valley deserts. Appl Microbiol Biotechnol 91(3):635-644. https://doi.org/10.1007/s00253-011-3256-9

Oehler S (2009) Feedback regulation of Lac repressor expression in Escherichia coli. J Bacteriol 191(16):5301-5303. https://doi.org/ 10.1128/JB.00427-09

Oh SY, Youn SY, Park MS, Kim HG, Baek NI, Li Z, Ji GE (2017) Synthesis of $\beta$-galactooligosaccharide using bifidobacterial $\beta$ galactosidase purified from recombinant Escherichia coli. J Microbiol Biotechnol 27(8):1392-1400. https://doi.org/10.4014/ jmb.1702.02058

Papadopoulos JS, Agarwala R (2007) COBALT: constraint-based alignment tool for multiple protein sequences. Bioinformatics (Oxford, England) 23(9):1073-1079. https://doi.org/10.1093/bioinformatics/ btm076

Qin J, Li R, Raes J, Arumugam M, Burgdorf KS, Manichanh C, Nielsen T, Pons N, Levenez F, Yamada T, Mende DR, Li J, Xu J, Li S, Li D, Cao J, Wang B, Liang H, Zheng H, Xie Y, Tap J, Lepage P, Bertalan M, Batto JM, Hansen T, Le Paslier D, Linneberg A, Nielsen HB, Pelletier E, Renault P, Sicheritz-Ponten T, Turner K, Zhu H, Yu C, Li S, Jian M, Zhou Y, Li Y, Zhang X, Li S, Qin N, Yang H, Wang J, Brunak S, Dore J, Guarner F, Kristiansen K, Pedersen O, Parkhill J, Weissenbach J, Bork P, Ehrlich SD, Wang J (2010) A human gut microbial gene catalogue established by metagenomic sequencing. Nature 464(7285):59-65. https://doi.org/10.1038/nature08821

Reuter S, Rusborg Nygaard A, Zimmermann W (1999) $\beta$ Galactooligosaccharide synthesis with $\beta$-galactosidases from Sulfolobus solfataricus, Aspergillus oryzae, and Escherichia coli. Enzym Microb Technol 25(6):509-516. https://doi.org/10.1016/ S0141-0229(99)00074-5

Rosano GL, Ceccarelli EA (2014) Recombinant protein expression in Escherichia coli: advances and challenges. Front Microbiol 5:172172. https://doi.org/10.3389/fmicb.2014.00172

Simon C, Daniel R (2011) Metagenomic analyses: past and future trends. Appl Environ Microbiol 77(4):1153-1161. https://doi.org/10.1128/ AEM.02345-10

Tasse L, Bercovici J, Pizzut-Serin S, Robe P, Tap J, Klopp C, Cantarel BL, Coutinho PM, Henrissat B, Leclerc M, Dore J, Monsan P, Remaud-Simeon M, Potocki-Veronese G (2010) Functional metagenomics to mine the human gut microbiome for dietary fiber catabolic enzymes. Genome Res 20(11):1605-1612. https://doi.org/ 10.1101/gr.108332.110

Tomasello G, Tralongo P, Damiani P, Sinagra E, Di Trapani B, Zeenny MN, Hussein IH, Jurjus A, Leone A (2014) Dismicrobism in inflammatory bowel disease and colorectal cancer: changes in response of colocytes. World J Gastroenterol 20(48):18121-18130. https://doi. org/10.3748/wjg.v20.i48.18121

Tomasello G, Mazzola M, Leone A, Sinagra E, Zummo G, Farina F, Damiani P, Cappello F, Gerges Geagea A, Jurjus A, Bou Assi T, Messina M, Carini F (2016) Nutrition, oxidative stress and intestinal dysbiosis: influence of diet on gut microbiota in inflammatory bowel diseases. Biomed Pap Med Fac Univ Palacky Olomouc Czech Repub 160(4):461-466. https://doi.org/10.5507/bp.2016.052

Torres DPM, Gonçalves MPF, Teixeira JA, Rodrigues LR (2010) Galactooligosaccharides: production, properties, applications and significance as prebiotics. Compr Rev Food Sci Food Saf 9(5): 438-454. https://doi.org/10.1111/j.1541-4337.2010.00119.x

Turroni F, Milani C, Duranti S, Mahony J, van Sinderen D, Ventura M (2018) Glycan utilization and cross-feeding activities by bifidobacteria. Trends Microbiol 26(4):339-350. https://doi.org/10. 1016/j.tim.2017.10.001

Uchiyama T, Miyazaki K, Yaoi K (2013) Characterization of a novel $\beta$ glucosidase from a compost microbial metagenome with strong transglycosylation activity. J Biol Chem 288(25):18325-18334. https://doi.org/10.1074/jbc.M113.471342

Van Laere KMA, Schols T, Beldman HA, Voragen AG (2000) Characterization of a novel $\beta$-galactosidase from Bifidobacterium adolescentis DSM 20083 active towards transgalactooligosaccharides. Appl Environ Microbiol 66(4):13791384

Vandenplas Y (2015) Lactose intolerance. Asia Pac J Clin Nutr 24(Suppl 1):S9-S13. https://doi.org/10.6133/apjen.2015.24.s1.02

Vera C, Guerrero C, Illanes A (2011) Determination of the transgalactosylation activity of Aspergillus oryzae $\beta$-galactosidase: effect of $\mathrm{pH}$, temperature, and galactose and glucose concentrations. Carbohydr Res 346(6):745-752. https://doi.org/10.1016/j.carres. 2011.01.030

Viborg AH, Katayama T, Abou Hachem M, Andersen MC, Nishimoto M, Clausen MH, Urashima T, Svensson B, Kitaoka M (2014) Distinct substrate specificities of three glycoside hydrolase family $42 \beta$-galactosidases from Bifidobacterium longum subsp. infantis ATCC 15697. Glycobiology 24(2):208-216. https://doi.org/10. 1093/glycob/cwt104

Walton GE, van den Heuvel EG, Kosters MH, Rastall RA, Tuohy KM, Gibson GR (2012) A randomised crossover study investigating the effects of galacto-oligosaccharides on the faecal microbiota in men and women over 50 years of age. Br J Nutr 107(10):1466-1475. https://doi.org/10.1017/s0007114511004697

Wierzbicka-Woś A, Bartasun P, Cieśliński H, Kur J (2013) Cloning and characterization of a novel cold-active glycoside hydrolase family 1 enzyme with $\beta$-glucosidase, $\beta$-fucosidase and $\beta$-galactosidase activities. BMC Biotechnol 13(1):22. https://doi.org/10.1186/14726750-13-22

Yi SH, Alli I, Park KH, Lee B (2011) Overexpression and characterization of a novel transgalactosylic and hydrolytic $\beta$-galactosidase from a human isolate Bifidobacterium breve B24. New Biotechnol 28(6):806-813. https://doi.org/10.1016/j.nbt.2011.07.006

Yu NY, Wagner JR, Laird MR, Melli G, Rey S, Lo R, Dao P, Sahinalp SC, Ester M, Foster LJ, Brinkman FS (2010) PSORTb 3.0: improved protein subcellular localization prediction with refined localization subcategories and predictive capabilities for all prokaryotes. Bioinformatics (Oxford, England) 26(13):1608-1615. https://doi. org/10.1093/bioinformatics/btq249

Zhang X, Li H, Li CJ, Ma T, Li G, Liu YH (2013) Metagenomic approach for the isolation of a thermostable $\beta$-galactosidase with high tolerance of galactose and glucose from soil samples of Turpan Basin. BMC Microbiol 13:237. https://doi.org/10.1186/14712180-13-237

Publisher's note Springer Nature remains neutral with regard to jurisdictional claims in published maps and institutional affiliations. 